\title{
Cell cycle control of Notch signaling and the functional regionalization of the neuroepithelium during vertebrate neurogenesis
}

\author{
MARIA JESÚS LATASA ${ }^{\#, 2}$, ELSA CISNEROS $\#, 1,3$ and JOSE MARÍA FRADE*,1 \\ ${ }^{1}$ Instituto Cajal, CSIC, ${ }^{2}$ Instituto de Investigaciones Biomédicas Alberto Sols, CSIC and ${ }^{3}$ Centro de Investigación \\ Biomédica en Red de Enfermedades Raras (CIBERER), Instituto de Salud Carlos III, Madrid, Spain
}

\begin{abstract}
A critical feature of vertebrate neural precursors is the to-and-fro displacement of their nuclei as cell cycle progresses, thus giving rise to a pseudostratified epithelium. This nuclear behavior, referred to as interkinetic nuclear migration (INM), is translated into the disposition of the cell somas at different orthogonal levels depending on the cell cycle stage they are. The finding that important regulators of neurogenesis, such as the proneural and neurogenic genes, undergo cyclic changes of expression and function in coordination with the cell cycle and the INM, and that the neurogenic process correlates with a particular window of the cell cycle, in coincidence with the apical localization in the neuroepithelium of neural precursors, is a novel concept that facilitates our understanding of the neurogenic process in vertebrates. As such, recent data support the notion that the three-dimensional structure of the neuroepithelium is crucial for proper neuronal production. In this review, we describe current knowledge of the molecular mechanisms involved in the differential expression and function of the proneural and neurogenic gene products along the cell cycle, and we discuss important consequences for vertebrate neurogenesis derived from this observation.
\end{abstract}

KEY WORDS: proneural gene, neurogenic gene, lateral inhibition, mRNA stability

During the initial stages of development, the vertebrate embryo undergoes a dorsal invagination of the neuroectoderm to form the neural tube. This structure, which subsequently will generate the brain and spinal cord as well as the neural crest derivatives, is initially a monostratified epithelium with its apical side forming the lumenal surface. As development proceeds neural precursors divide vigorously in an unsynchronized manner, increasing dramatically its cellular density and acquiring a highly packed, pseudostratified disposition characterized by the presence of their nuclei at different levels depending on the cell cycle stage they are (Fig. 1). A hallmark of the neural precursors is therefore the to-and-fro displacement of the nucleus during the cell cycle, a process that is referred to as interkinetic nuclear migration (INM) (Sauer, 1935; Sauer and Walker, 1959; Sidman et al., 1959; Fujita, 1962; Takahashi et al., 1993; Hayes and Nowakowski, 2000). This nuclear movement spans the entire apical-basal axis of the cell, with the nucleus migrating to the basal side during the first gap (G1) phase of the cell cycle, staying at the basal side during the DNA synthesis phase (S-phase), migrating back to the apical side during the second gap (G2) phase, and undergoing mitosis (M) at the apical side. This cellular behavior, which has been conserved throughout evolution as it can be observed in some invertebrate neuroepithelia such as the eye imaginal disc of

\footnotetext{
Abbreviations used in this paper: Adcyap, adenylate cyclase-activating polypeptide; APC, anaphase-promoting complex; ARE, AU-rich element; asc, achaete scute; ascl, asc-like; ato, atonal; atoh, ato homolog; bHLH, basic helix-loophelix; CDK, cyclin-dependent kinase; CKI, CDK inhibitor; csnk, casein kinase; Dll1, Delta-like 1; ELAV, embryonic lethal abnormal vision; elavl, ELAV-like; emc, extra macrochaetae; E (spl), enhancer of split; Esr, enhancer of split related; Hes, hairy and enhancer of split; Her, hairy and enhancer of split related; HLH, helix-loop-helix; Id, inhibitor of differentiation; INM, interkinetic nuclear migration; Lfng, lunatic fringe; miRNA, microRNA; neurog, neurogenin; NICD, notch intracellular domain; RBP, RNA-binding protein; $\mathrm{Su}(\mathrm{H})$, suppressor of Hairless; Shh, sonic hedgehog; Tacc, transforming acidic coiled-coil.
}

*Address correspondence to: Dr. Jose María Frade. Instituto Cajal, (CSIC), Avda. Dr. Arce 37, E-28002 Madrid, Spain. Fax: +34-91-585-4754. e-mail: frade@cajal.csic.es

\#Note: Both authors contributed equally to this work

Accepted: 10 October 2008. Published online: 22 May 2009.

ISSN: Online 1696-3547, Print 0214-6282

(C) 2009 UBC Press

Printed in Spain 


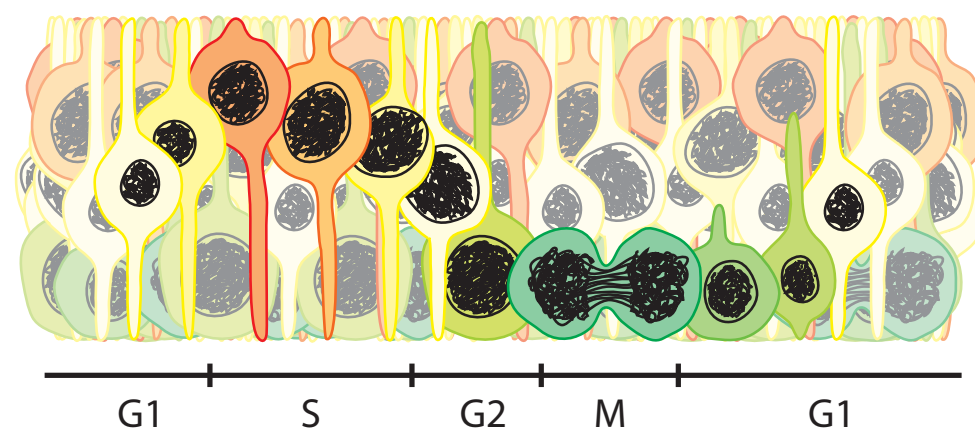

Fig. 1. Scheme of the interkinetic nuclear migration observed in vertebrate neuroepithelia. Neural precursors displace their nuclei as they progress through the cell cycle. During G1, nucleiare displaced to the basal surface (top), where they undergo DNA replication (S). Once S-phase is finished, nuclei move back to the apical portion of the neuroepithelium (bottom) as they go through G2, and then they divide to give rise to two daughter cells (M). G1, first gap phase; $G 2$, second gap phase; $M$, mitosis; $S$, DNA synthesis phase.

Drosophila (Tomlinson, 1988), likely results from the epithelial nature of this tissue characterized by the attachment of neural precursors to each other by apically-located adherens junctions. The adherens junctions are belt-like junctions composed of cadherins, which are linked to a ring-like cytoskeleton of actin microfilaments just above the centrosome (Chenn et al., 1998). This tight interaction among neural precursors forces them to displace their nuclei to the apical side in order to acquire a round morphology during $\mathrm{M}$, and to the basal side during interphase in order to make space for other neural precursors disposed to undergo $\mathrm{M}$.

So far, a few reviews have been published dealing either directly (Frade, 2002; Baye and Link, 2008; Miyata, 2008) or indirectly (Gotz and Huttner, 2005) with INM. In this review we will focus on the interplay among INM, cell cycle, and neurogenesis, discussing on molecular mechanisms coordinating the neurogenic process with the cell cycle and how the three-dimensional structure of the neuroepithelium is crucial for the proper neurogenic process.

\section{Molecular and cellular mechanisms regulating INM}

Nuclear positioning in eukaryotic cells depends on active mechanisms which move nuclei within the cytoplasm and maintain them in the correct cellular location (Reinsch and Gonczy, 1998). In many cells, nuclear positioning is a microtubule-dependent process with relative participation of the actin cytoskeleton. This seems to be the case for INM in the vertebrate neuroepithelium since a number of pharmacological studies carried out in this tissue indicate that INM is dependent on the integrity of both actin and microtubule cytoskeleton (Karfunkel, 1972; Messier and Auclair, 1977; Webster and Langman, 1978; Murciano et al., 2002).

A major mechanism for nuclear positioning in eukaryotic cells is based on a tight association of the nucleus with a microtubule organizing center such as the centrosome (Reinsch and Gonczy, 1998). Recent evidence demonstrates that centrosome and microtubule-associated proteins play a major role in regulating INM (Xie et al., 2007) but, unlike other examples where nuclei follow the centrosome during migration, in neural precursors the centrosome remains apically located (Hinds and Ruffett, 1971; Astrom and Webster, 1991; Chenn et al., 1998). Therefore, the length of the microtubule network coupling the nucleus with the centrosome must be dynamically regulated. In this regard, Xie et al. (2007) have shown that Cep120, a centrosomal protein preferentially expressed in neural precursors, can interact with transforming acidic coiled-coil protein (Tacc)3, a microtubule-associated protein involved in microtubule growth, and recruit it to the centrosome. Both Cep120 and Tacc3 are crucial for coupling the centrosome and the nucleus, and Tacc3 could regulate the changes in the distance between these organelles that is observed during INM (Xie et al., 2007). Indirect evidence also suggests that the minus end-directed motor dynein participates in the nuclear movement in neural precursors, as occurs in several other examples of nuclear positioning (Reinsch and Gonczy, 1998). As such, mutations in the dynein-regulating protein Lis1 (Wynshaw-Boris and Gambello, 2001) are known to deregulate INM (Gambello et al., 2003; Tsai et al., 2005; Xie et al., 2007). Furthermore, truncating mutations in the dyneininteracting protein dynactin are responsible for glued phenotypes in Drosophila (Schroer, 2004). In these mutant flies, the nuclei of photoreceptor cells fail to move apically toward the minusend of microtubules and instead remain at more basal locations, a phenotype that can be suppressed by mutations in subunits of kinesin, the plus-end directed microtubule motor (Whited et al., 2004). INM is also affected in zebrafish dynactin-1 mutants. In the developing retina of these mutants interkinetic nuclei migrate faster to the basal surface and further basally, take longer to return, and often enter $M$ before they have reached the apical domain (Del Bene et al., 2008).

Another regulator of INM in vertebrates is casein kinase (Csnk)2, a Ser/Thr kinase able to phosphorylate both molecular motors and cytoskeletal components (Canton and Litchfield, 2006). Csnk2 is expressed by retinal precursors and pharmacological inhibition of this kinase blocked INM in a dose-dependent way (Carneiro et al., 2008), but the molecular mechanism behind the function of Csnk2 in INM is currently unknown. The transcription factor Pax6 has also been shown to participate in nuclear displacement to the apical surface during INM in cortical precursors, likely due to its participation in the stabilization of the centrosome at the apical side of the neuroepithelium (Tamai et al., 2007).

In specific areas of the developing vertebrate nervous system, such as the retina, external factors to the neuroepithelium have also been shown to modulate INM. The developing retina is surrounded by the prospective pigment epithelium, a monostratified epithelial structure which will give rise to a layer of pigmented cells in the adult eye, and that can modulate the development of the neural retina (Frade et al., 1999). The prospective pigment epithelium has been shown to be coupled with the developing retina by gap junction-dependent $\mathrm{Ca}^{2+}$ activity (Pearson et al., 2004). INM has been associated with $\mathrm{Ca}^{2+}$ transients, and gap-junctional communication is an important requirement for the maintenance of normal INM in retinal precursor cells (Pearson et al., 2005). The actual mechanism by which gap junctions modulate INM is currently unknown.

\section{Molecular and cellular mechanisms regulating cell cycle progression}

The cell cycle is a highly conserved mechanism by which eukaryotic cells proliferate. This process is typically divided into 
four phases: G1, S, G2, and M (Murray and Hunt, 1993) (Fig. 2). The G1, S, and G2 stages are globally referred to as interphase, in contrast with $\mathrm{M}$, the phase when the cell generates two daughter cells with equal DNA content and chromosome number. Progression through these phases is regulated by the sequential expression, activation, and inhibition of cyclin-dependent kinase (CDK) complexes and their activating partners, the cyclins, as well as CDK inhibitors (CKIs) (Lees, 1995). Cycling cells usually exit the cell cycle after having completed $M$ and remain in a quiescent $\mathrm{G} 0$ state.

In proliferating cells, progress through the cell cycle is tightly controlled by checkpoints. These checkpoints function as molecular switches that ensure the completion of critical events in one phase of the cell cycle before entering of the next phase, thereby coordinating cell growth with cell proliferation. Two major check points have been described, the G1/S check point, that allows a cell to initiate replication of its DNA; and the G2/M check point, that controls whether DNA replication has been correctly performed before the cell divide.

In mammals, seven CDKs and eight cyclins have been described to date, of which the best studied will be briefly introduced here (for review, see Murray and Hunt, 1993; Grana and Reddy, 1995; Lees, 1995; Morgan, 1997). Following mitogenic stimulation, D-type cyclins are synthesized and bind and activate CDK4 and CDK6, thereby allowing cells to induce cyclin E expression and leave the G1 phase (Sherr et al., 1994). Cyclin E associates with CDK2 (Sherr, 1994). This cyclin E/CDK2 complex is necessary for transition into $S$ phase. DNA synthesis is associated with an active cyclin A/CDK2 complex (Grana and Reddy, 1995). When DNA replication is completed, cyclin A forms a complex

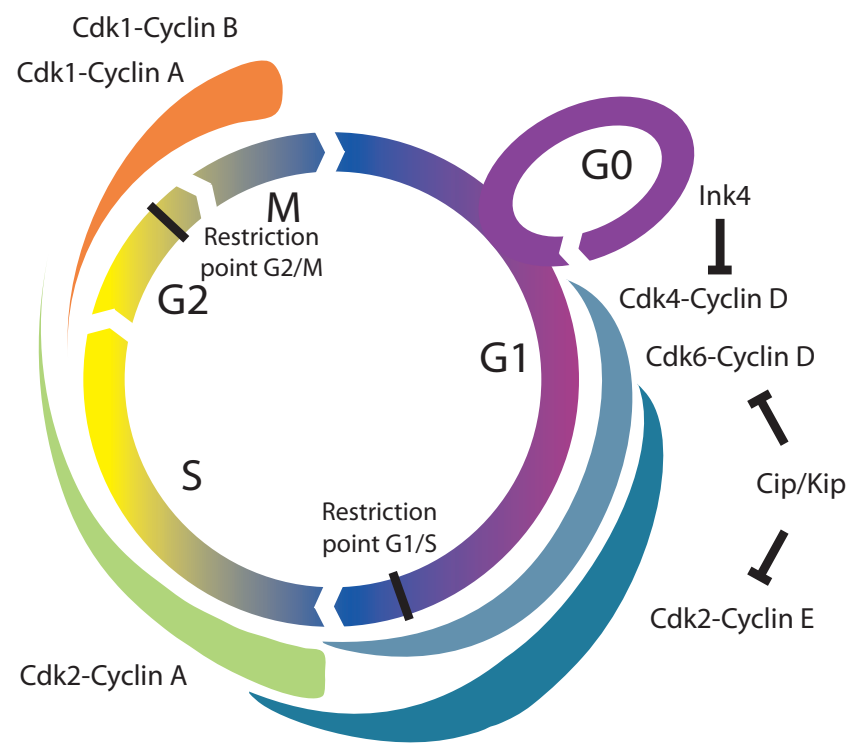

Fig. 2. Schematic diagram of cell cycle and its main regulators. Progression through the cell cycle is regulated by cyclin/CDK complexes and their inhibitors (Ink4 family and Kip/Cip family). Two main restriction points have been described, that control whether cells enter a new round of DNA replication (G1/S check point), and whether DNA replication has been correctly performed before the cell divide (G2/M check point). GO, quiescent state; 11 , first gap phase; G2: second gap phase; $M$, mitosis; S, DNA synthesis phase. with CDK1, also termed CDC2, and drives the cell through G2 phase (Sherr, 1994). At the G2/M transition, cyclin A is degraded and CDK1 associates with newly synthesized cyclin B (Grana and Reddy, 1995). The cyclin B/CDK1 complex is required for progression through M (Grana and Reddy, 1995). In late M phase, cyclin $B / C D K 1$ is inactivated due to the degradation of cyclin $B$ by the anaphase-promoting complex (APC), an E3-ubiquitin ligase (Harper, 2002; Peters, 2002), and the cell complete M followed by entry into $\mathrm{G} 1$ (or $\mathrm{G} 0$ if the daughter cell is programmed to remain quiescent).

Two families of proteins inhibit the activity of cyclin-CDK complexes (Lees, 1995; Sherr and Roberts, 1999). Members of the Kip/Cip family of proteins (p21 ${ }^{\text {Cip } 1}, \mathrm{p} 27^{\text {Kip1 }}$, and $\mathrm{p} 57^{\mathrm{Kip} 2}$ ) regulate the activity of all the G1 cyclin-CDK complexes and, to a lesser extent, cyclin B/CDK1, while members of the Ink4 family

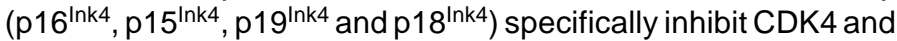
CDK6 (Sherr and Roberts, 1999). As it occurs to CDKs and cyclins, the activity of CKIs is tightly regulated by transcription, translation, and ubiquitin-mediated proteolysis (Sherr and Roberts, 1999).

\section{Synchrony of the INM and the cell cycle}

One hallmark of INM is the coordination of the nuclear movement with the cell cycle. This coordination has been studied pharmacologically. When nucleokinesis is blocked by drugs inhibiting microtubule (Karfunkel, 1972) or actin (Karfunkel, 1972; Messier and Auclair, 1977; Webster and Langman, 1978; Murciano et al., 2002) polymerization, cell cycle still can progress, thus suggesting that, although INM and cell cycle progression are tightly coordinated in the vertebrate neuroepithelium, both processes can actually be molecularly dissociated. A similar conclusion can be raised from the work by Tamai et al. (2007) and Del Bene et al. (2008). The former authors found that in the ventricular zone of the Pax6-deficient cerebral wall, coordination between the cell cycle and INM is disrupted as neural precursor cells lacking Pax6 often exhibit premature displacement of their nuclei to the apical side during S-phase. Likewise, Del Bene et al.,2008) described the presence of alterations of INM and ectopic mitoses in the retina of zebrafish dynactin-1 mutant embryos. In accordance with this conclusion, inhibition of cell cycle progression in $\mathrm{S}$-phase with hydroxyurea, a reversible ribonucleoside reductase inhibitor that blocks deoxynucleotide synthesis, inhibits DNA replication, and induces synchronization in S-phase, has been shown not to interfere with the nuclear movement of neural precursors to the apical side of the neuroepithelium (Murciano et al., 2002). In contrast with these results, prevention of cell cycle progression in $\mathrm{M}$ by colchicine inhibits nuclear displacement to the basal neuroepithelium (Waterson et al., 1956). This lack of basally-oriented nuclear migration induced by colchicine is likely due to the inhibition of the apical-basal microtubule network required for the basal displacement of the nuclei (see above). These studies have been recently confirmed by Ueno et al. (2006) who used 5-azacytidine to induce G2/M-phase arrest, also resulting in the inhibition of basally-oriented nuclear migration in the neuroepithelium. The latter authors also used cyclophosphamide to induce S-phase arrest, and in contrast with previous findings, they found that this drug was able to prevent apically-oriented nuclear migration in neural precursors. Whether the effects of cyclophosphamide on INM directly derive from S-phase arrest or 
additional side effects induced by this drug could account for this observation remains currently unknown.

\section{Molecular mechanisms regulating neurogenesis in vertebrates}

The process of neurogenesis implies the production of different neuron types in the adequate number and position. As all neurons in the vertebrate central nervous system (CNS) derive from the neural tube, CNS correct formation requires the precise regulation of all the events that take place during its development. The proneural genes and the Delta-Notch signaling pathway actively participate and determine the accuracy of the neurogenesis process, and coordinate neurogenesis with the cell cycle (see below).

\section{Proneural genes}

Genetic studies in Drosophila and vertebrates have proved that a limited number of genes coding for transcription factors of the basic helix-loop-helix (bHLH) family, known as proneural genes, are necessary for the selection of neural precursors and for their commitment to differentiate along specific neural fates (Bertrand et al., 2002). There are two families of proneural genes characterized by their homology to achaete-scute (asc) complex and atonal(ato) in Drosophila. In vertebrates, ascfamily has four members: the asc-likegene (asch), which is present in all species analyzed to date (asc/1 in zebrafish, Xenopus, chick and mouse), and three other genes, each one of them has been found in one single vertebrate specie (asc/3 in Xenopus, asc/4 in chick and asc/2 in mammals). Only asc/1 in mouse and asc/3/asc/4 have been shown to be implicated in nervous system development (Bertrand et al., 2002). As well, the genes belonging to the ato family in vertebrates can be divided in three subfamilies attending at differences in their basic domain: neurogenin (neurog), ato homologues (atoh) and NeuroD (Hassan and Bellen, 2000).

In Drosophila, proneural genes are first expressed in groups of quiescent ectodermal cells (i.e. "proneural clusters") that have both epidermal and neuronal potential, and that determine the region where the CNS or the peripheral nervous system will develop (Campuzano and Modolell, 1992). Proneural activity results in the commitment of precursor cells to a neural fate, but these cells remain multipotent, and divide giving rise to both neurons and glia. In contrast, vertebrate proneural genes are first expressed in precursor cells that are already specified for a neural fate and are self-renewing. In this case, proneural activity results in the generation of cells that have limited mitotic potential, giving rise to postmitotic neurons in many instances (Bertrand et al., 2002).

Proneural genes are sufficient and necessary to promote neural precursor cells formation from the Drosophila ectoderm (Jimenez and Modolell, 1993); and lack of these genes in vertebrates implies the loss of neurons, while their ectopic expression in regions where they are not normally expressed induces the development of ectopic neurons. Thus, the proneural gene neurog 1 has been shown to induce ectopic neurogenesis and ectopic expression of NeuroDmRNA in Xenopusembryos, indicating that the properties of neurog are analogous to those of the Drosophila proneural genes (Ma et al., 1996). Gene disruption studies indicate that mouse ascl1 function is required for the proper development of the autonomic nervous system and olfactory neurons (Guillemot et al., 1993). When ascl3 is expressed at high levels in Xenopus embryos the neural tube expands, and low levels of this gene generates ectopic differentiated neurons in this model system (Ferreiro etal., 1994; Turner and Weintraub, 1994). Mouse NeuroD3 has also been shown to induce ectopic neuronal formation when injected into Xenopusembryos (McCormick et al., 1996).

Proneural proteins bind DNA as heterodimeric complexes with E proteins, a type of bHLH proteins expressed ubiquitously. Since heterodimerization is required for these proteins to bind DNA, the factors that interfere with this heterodimerization act as passive repressors of proneural genes activity. Hence, the gene products belonging to the helix-loop-helix (HLH) type of factors, extra macrochaetae (emc) in Drosophila and inhibitor of differentiation $(/ d)$ in vertebrates, compete with proneural proteins since they bind with high affinity to $E$ proteins. Since these proteins lack the DNA binding domain, the resulting heterodimers with the repressor proteins cannot bind to DNA (Massari and Murre, 2000). Furthermore, the Enhancer of split (E(sp/) factors in Drosophila or the Hes/Her/Esrfamily in vertebrates are inhibitors of proneural genes which act as transcriptional repressors when bound to DNA, although it is also possible that they act by interfering in the formation of proneural proteins and $\mathrm{E}$ proteins complexes (Davis and Turner, 2001).

\section{Delta-Notch signaling}

The Notch receptor and its ligands, Delta and Serrate (known as Jagged in mammals), are transmembrane proteins with large extracellular domains, encoded by the so-called neurogenic genes. Ligand binding promotes two proteolytic cleavages which result in release of the Notch intracellular domain (NICD) and its translocation to the nucleus (Weinmaster, 2000). Then, NICD cooperates with the DNA-binding protein CSL (named after CBF1, $\mathrm{Su}(\mathrm{H})$ and LAG-1) and its coactivator Mastermind to promote transcription of its major targets, E(spl)or the Hes/Her/Esrfamily members in vertebrates. Therefore, Notch activation by its ligand lead to transcriptional repression of proneural genes (Bray, 2006). Glycosyltransferases like Fringe alter the capability of ligands to activate Notch. Thus, modifications of extracellular domain of Notch by Lunatic fringe (Lfng), the mammalian homologue of Fringe, potentiates Delta binding and promotes Notch activity (Haines and Irvine, 2003).

\section{Neural precursor selection by lateral inhibition}

An essential role of proneural proteins is to restrict their own activity to single neural precursor cells. Proneural genes inhibit their own expression in adjacent cells, thereby preventing these cells from differentiating. This is achieved through activation of the Notch signaling pathway, in a process termed "lateral inhibition", which is initiated by the induction of a Notch ligand (Fig. 3). In vertebrates, ascl1 and neurogs can induce direct and dosedependent expression of Delta-like 1 (DI/1) (Castro et al., 2006). Expression of the Delta ligand in the precursors activates the Notch signaling cascade in neighboring cells, resulting in the expression of repressors, E(spl) genes in Drosophila and Hes/ Her/Esrin vertebrates that, in turn, directly downregulate proneural gene expression (Bertrand et al., 2002). Through lateral inhibition, therefore, differences between neighbors caused by 
stochastic events are stabilized and amplified. Eventually, the initial pattern is refined and proneural gene expression is restricted to single cells that enter a neural differentiation pathway (Artavanis-Tsakonas et al., 1999)

Therefore, neural precursor fate control involves two phases. First, proneural genes are expressed or activated at low levels and a reversible selection of neural precursors takes place. Then, proneural genes reach high levels of expression or activity and neural precursors undergo an irreversible commitment to the neural fate (Culi and Modolell, 1998; Bertrand et al., 2002; Kintner, 2002).

\section{Molecular and cellular mechanism coordinating cell cycle and INM with neurogenesis}

Neurogenesis in the CNS involves proliferation and subsequent differentiation of neural precursor cells located at the apical portion of the neuroepithelium. Coordination between proliferation and differentiation is required for the correct formation of CNS since alterations in the balance between both processes are translated into dramatic changes in the net production of neurons as well as the growth of the neuroepithelium (Murciano et al., 2002). Furthermore, any disturbance of the three-dimensional structure of the neuroepithelium results in a higher rate of neuronal differentiation and the depletion of the neural precursor pool (see below; Murciano et al., 2002; Xie et al., 2007; Del Bene et al., 2008).

In recent years, a large body of evidence has demonstrated that some of the key factors that regulate progression through the cell cycle have an effect on neural cell fate, whereas several determination and differentiation factors have a role in cell cycle regulation (Ohnuma et al., 2001). Nevertheless, only a few studies have focused on the specific expression and function of the regulators of neurogenesis at particular cell cycle stages and their differential localization within the neuroepithelium. In the following lines we will summarize what is known on all these important aspects in CNS neurogenesis.

\section{Cell cycle elements regulating determination/differentiation}

Many of the G1 phase components affect neural determination. A key cell cycle restriction point is located at the end of $\mathrm{G} 1$ phase. If cells pass this point, they will almost invariably complete the cell cycle. In order to differentiate, neural precursor cells need to exit the cell cycle in G1 and enter G0 without passing the cell cycle restriction point.

During development, downregulation of CDKs and cyclins, as well as induction of CKIs lead to cell cycle exit (Gui et al., 2007). In particular, p19 Ink4 and $\mathrm{p} 27^{\mathrm{Kip} 2}$ are required to maintain the quiescent state of neurons in the cortex and hippocampus (Zindy et al., 1999). Numerous studies have also shown that factors whose function is inhibiting cell cycle are able to activate determination pathways. In the Xenopus retina, arrest in $\mathrm{G} 1$ phase by CKI p27 Xic1, a Kip/Cip family homolog, potentiates proneural gene Xenopus atoh7. Conversely, activation of cell cycle by cyclin E1, essential for entry into S-phase, reduces its activity (Ohnuma et al., 2002). Data suggest that $\mathrm{p} 27^{\mathrm{Xic} 1}$ may enhance neurogenesis by stabilizing the bHLH protein neurogenin (Vernon et al., 2003). On the other hand, elements mediating progression through the cell cycle could have a role on differentiation process. Thus, cyclin D1 represses NeuroD transcription in mammalian cells culture and this is independent from its effects on the cell cycle (Ratineau et al., 2002). The APC, whose role as mediator of $M$ and G1 transitions has been well established, has, along with its coactivator Cdh1, effects upon the nervous system ranging from regulation of axon growth and patterning to development of synapses and neural survival (Kim and Bonni, 2007).

Geminin is a dual function molecule with roles in regulating both DNA replication and neural cell fate during embryonic development. This protein prevents reinitiation of replication within a single cell cycle to maintain chromosomal integrity and euploidy. Its levels rise during S-phase and it is degraded during $M$ enabling a new round of DNA replication to be initiated in the subsequent S-phase. On the other hand, this protein controls the transition from proliferating neural precursor to differentiated post-mitotic neuron by modulating interactions between SWI/ SNF chromatin-remodeling complex and bHLH transcription factors that are critical for neurogenesis or through interactions with Six 3 and Hox transcriptions factors and Polycomb group proteins (Seo and Kroll, 2006).

\section{Determination/differentiation factors regulating cell cycle progression}

Some of the transcription factors that control patterning of CNS at early stages of development mediate cell cycle progression within the regions where they are expressed. For instance, mammalian factor Emx2 promotes expansion of cortical precursors regulating symmetric cell divisions in the developing cortex (Heins et al., 2001). Over-expression of eye-specific transcription factors Optix2/Six6 (Zuber et al., 1999), Six3 (Kobayashi et al., 2001) and Rx1 (Andreazzoli etal., 1999) in Xenopusand zebrafish embryos results in giant eyes. All these factors bind to groucho, whose over-expression also leads to increased eye size (LopezRios et al., 2003). Eye-specific factors may work by repressing

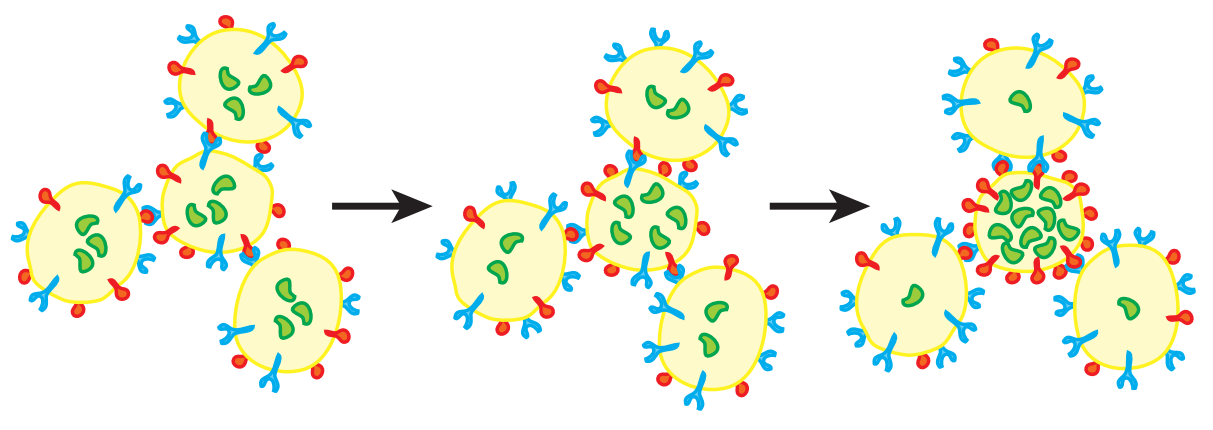

Fig. 3. Lateral inhibition with feed-back. Proneural genes (green) are initially expressed at similar levels in a cluster of equivalent cells. These genes encode bHLH transcription factors responsible for neuronal differentiation as well as for Delta ligand (red) expression. Delta ligand activates Notch (blue) in adjacent cells, thus resulting in the inhibition of proneural gene expression in these cells. A stochastic increase of Delta ligand levels in a particular cell is translated into reduced expression of Delta and proneural genes in the adjacent cells, thus facilitating the upregulation of the latter genes in the cell, which becomes differentiated. 
cell cycle inhibitors. In fact, knockouts of Optixz/Six6 show upregulation of $\mathrm{p} 27^{\mathrm{Kip} 1}$ and $\mathrm{p} 19^{\mathrm{Ink} 4}$ (Li et al., 2002).

Furthermore, various determination factors facilitate differentiation. For instance, neurog2 overexpression in the chick embryo spinal cord results in cell cycle withdrawal and early differentiation of neural precursors (Farah et al., 2000). Also, other proneural genes act at $\mathrm{G} 1$ cell cycle phase allowing cells to exit the cell cycle to G0 upregulating CKIs like p16 ${ }^{\text {Ink4 }}, \mathrm{p} 21^{\mathrm{Cip} 1}$ and p27 Kip1. Thus, transitory activation of NeuroD2, mouse ascl1 and neurog1 can convert mouse $\mathrm{P} 19$ embryonic carcinoma cells into differentiated neurons by induction of $\mathrm{p} 27^{\mathrm{Kip} 1}$ and arrest of cell cycle in G1 (Farah et al., 2000). Likewise, proneural gene NeuroD causes p2 $1^{\text {Cip1 }}$ direct activation in HeLa cells (Farah et al., 2000).

But, cell cycle phases other than $\mathrm{G} 1$ are regulated by determination/differentiation factors as well. Drosophila Tramtrack protein inhibits cell cycle progression throughout cyclin $\mathrm{E}$ inhibition (Badenhorst, 2001). In Drosophilawing development, asc activity induces transient G2 phase arrest by downregulation of the Minducing phosphatase string (cdc25) (Johnston and Edgar, 1998).

In the same manner, external determination factors and proliferating signals act throughout cell cycle components present in G1 phase. Wnt regulates cell cycle by modulation of cyclins D1 and D2, as well as Myc (Kioussi et al., 2002; Baek et al., 2003), whereas Sonic hedgehog (Shh) modulates cyclin D1 and Mycn transcription (Kenney et al., 2003; Oliver et al., 2003; Lobjois et al., 2004). Pituitary adenylate cyclase-activating polypeptide (Adcyap) is a neuropeptide expressed in growth zones of the brain. Via the Shh glycoprotein, the small GTPase Rho or the CKI p57Kip2, Adcyap1b inhibits the cyclin E-CDK2 complex. This signaling may elicit cortical precursor withdrawal from the cell cycle, antagonizing mitogenic stimulators, and promote neuronal differentiation (Meyer, 2006).

\section{Cell-cycle dependent expression and function of regulators of neurogenesis in the neuroepithelium}

The expression of particular CNS determinants has been shown to be associated to specific cell cycle stages. Prox1, for example, a homeodomain protein involved in horizontal retina cells determination, is predominantly expressed during G2 phase (Dyer et al., 2003). Likewise, Dyrk1a, a protein required for proliferation, is expressed by neural precursors during M and G1 phase, and it is asymmetrically inherited, probably, in order to define proliferation-differentiation transition (Hammerle et al., 2002). In the same manner, glial cells determinant Tramtrack is upregulated during S-phase in Drosophila (Badenhorst, 2001).

The expression levels of neurogenic and proneural genes have also been shown to oscillate as the neural precursors proceed through the cell cycle. During vertebrate development, Notch 1expression increases at the neuroepithelium apical region (Lindsell etal., 1996; Myat etal., 1996; Henrique et al., 1997). DI/1 can also be detected in this region, expressed by neural precursors committed to neuronal fate once they have completed their final S-phase (Henrique et al., 1995; Myat et al., 1996; Murciano et al., 2002). Therefore, the expression of both Notch1 and its ligand D//1in neural precursor cells is restricted to the region of the neuroepithelium where the neural precursors going through G2/ M/G1 are located (Murciano et al., 2002; Cisneros et al., 2008). In contrast with this notion, Del Bene et al. (2008) found that in the embryonic zebrafish retina $d / b$ and $d / c$ mRNAs were mainly expressed at the basal neuroepithelium. Surprisingly, these authors found evidence of Notch-specific activity only at the apical neuroepithelium, suggesting that other Delta ligands could activate Notch in that region.

The capacity to differentially express Notch1 and DI/1 in a cellcycle dependent manner is an intrinsic characteristic of the neural precursors. Indeed, in vitroisolated neural precursors from chicken (E4) and mouse (E11) brain neuroepithelia, chemically synchronized either in $\mathrm{M}$ or S-phase, showed reduced expression levels of Notch1 and Delta1 mRNAs when synchronized in the latter stage, as observed in vivo (Cisneros et al., 2008). Accordingly, freshly dissociated neural precursors in G2/M were observed to have higher levels of Notch1 than those in S-phase (Cisneros et al., 2008). Id2 expression levels were diminished when neural precursors were synchronized in $\mathrm{M}$, but not when synchronized in S-phase, proving that the reduced mRNAs levels for Notch1 and Delta1 during S-phase is specific and not a consequence of the neural precursors isolation and culture, and posterior chemical treatment for synchronization.

The glycosyltransferase Lfng modifies Notch extracellular domain and facilitates Notch activation by DIl1 (Haines and Irvine, 2003). Interestingly, its mRNA is also expressed in the apical region of the neuroepithelium (Cisneros et al., 2008), showing the same expression pattern as Notch1. This suggests that Notch activity is enhanced in neural precursors undergoing $M$. The cell cycle-dependent changing expression of $L$ fng may also reflect Notch 1 activity, since $L$ fng promoter responds to Notch activation in the presomitic mesoderm (Morales et al., 2002), although other contributions to its regulation cannot be discounted.

Co-localization of Notch 1 receptor, DI/1ligand and LfngmRNAs is not enough to prove activation of Notch signaling cascade in the apical region of the neuroepithelium. This notion was proved to be true as the expression of the downstream effectors of Notch, Hes 1 and Hes5 (Davis and Turner, 2001; Fior and Henrique, 2005; Bray, 2006; Nelson et al., 2006), was also observed to be cell cycle dependent. Hes5 expression in the apical region of the neuroepithelium (Nelson et al., 2006; Cisneros et al., 2008), as well as the increment of its mRNA levels consequently to the high density of the cultured neural precursors synchronized in $\mathrm{M}$ but not in S-phase (Cisneros et al., 2008), imply that Notch activity in neural precursors is maximal during $\mathrm{M}$. Hes 1 expression is also increased in high-cell density cultured neural precursors synchronized in $\mathrm{M}$, but not in S-phase, although at a lesser degree when compared to Hes5expression (Cisneros et al., 2008), likely as the result of Hes 1 expression regulation being less dependent on Notch activity (de la Pompa et al., 1997). In accordance with these studies, the downstream effector of Notch her4 has been shown to increase its transcription in neural precursors from zebrafish embryonic retina as they move from the basal to the apical end of the neuroepithelim (Del Bene et al., 2008), further indicating that Notch signaling is activated during G2/M. Tokunaga et al. (2004) have shown that the presence of NICD, an evidence for Notch activity, can be detected in a minority of nuclei undergoing $S$ phase (i.e. incorporating BrdU), and that the cells expressing active Notch1 were located closer to the ventricular surface than those expressing the Notch1 receptor, suggesting that Notch1signaling is activated in a cell cycle phase-dependent manner. Nevertheless, in this study NICD was not detected in mouse neural precursors undergoing M-phase (Tokunaga et al., 2004). 
Del Bene et al. (2008) have also shown NICD-specific immunoreactivity in the nuclei of neural precursors located at the ventricular surface of the mouse embryonic retina. In another study, immunoreactivity for NICD has been described throughout the CNS neuroepithelium closely resembling that of BrdU staining (Del Monte et al., 2007), therefore indicating that Notch1 is active in proliferating cells. Nevertheless, co-localization of NICD with $\mathrm{BrdU}$ (i.e. in neural precursors undergoing S-phase) or lack of this co-localization was not showed by these authors. Further and more detailed studies are necessary in order to precisely determine the activation and function of Notch1 along cell cycle. Expression of Notch1 effectors such as Hes 1 and Hes 5 may be subject to autonomous regulation in a cell-cycle dependent manner, just as it has been described for Nocth 1 and DI/1, and we have to take into account the delay existing between RNA presence in the cell and its translation, if any, into functional proteins. All these facts may account for the existing divergences among the mentioned studies.

The capacity of the developing chick neuroepithelium to express DII1, Neurog1 and Neurog2 is reduced during S-phase in vivo, even though Notch1levels are also reduced in this cell-cycle phase (Murciano et al., 2002) and, therefore, no inhibitory signals seem to be regulating the previously mentioned genes. Since DI/1 is susceptible to regulation by the transcription factors codified by the proneural genes (Kunisch et al., 1994; Heitzler et al., 1996; Castro et al., 2006), Dl/1expression can be a measurement of the neurogenic capacity of neural precursors. As expected, DI/1 mRNA levels are diminished under conditions where Hes1 and Hes 5 levels are high due to high-density culture conditions and synchronization in M (Cisneros et al., 2008). Nevertheless, the low level of expression of Notch effectors Hes 1 and Hes5during S-phase does not translate into an increase of DI/1 expression, not even under high-density culture conditions nor when the neural precursors were free of Notch inhibitory signals at lowdensity culture conditions (Cisneros et al., 2008). Therefore, data indicate the absence of neurogenic capacity during S-phase. The mechanism that prevents DII1, Neurog1 and Neurog2expression during S-phase is unknown at present. Hes1 presence may, in a Notch-independent manner, interfere with the mentioned genes during S-phase. Indeed, the observed oscillations of Hes1 protein levels (Shimojo et al., 2008) could account for the downregulation of DII1, Neurog1 and Neurog2 expression during S-phase. Low Notch1 expression levels during S-phase could also account for the reduced DI/1, Neurog1 and Neurog2 expression at this cell cycle stage. In this regard, Notch has been shown to present two sequential and opposite effects during neural development. Notch has the capacity to induce proneural gene expression in areas where it initially becomes expressed. This effect has been demonstrated in the Drosophila eye imaginal disc (Baker and $\mathrm{Yu}$, 1997), the developing chick inner ear (Daudet and Lewis, 2005), and in embryonic stem cells (Lowell et al., 2006). Later in development, Notch acts as a classical mediator of lateral inhibition. Therefore, the decrease of Notch1 expression levels during Sphase could explain the observed diminished neurogenic capacity of neural precursors during this cell cycle phase.

\section{Regulation of Notch1 and DII1 levels along the cell cycle}

Since Notch1 and DI/1 mRNA levels decrease during S-phase in vertebrate neuroepithelia, the different mechanisms involved in gene expression regulation, such as the transcription rate and mRNA stability, must take account for the changing expression levels of these genes. In order to determine the contribution of transcriptional regulation on the mRNAs levels, promoter studies were performed in the context of a mouse neural precursor line, b2T-H2 (Nardelli et al., 2003), both in transient and stably transfections. Mouse promoter fragments for Nocth1 and DII1, and whose functionality had been already described (Beckers et al., 2000; Yugawa et al., 2007), do not differentially activate the expression of a reporter gene in cells synchronized either in $\mathrm{M}$ or S-phase (unpublished data). But far away located enhancers or other regulatory sequences situated within the untranslated regions of the gene, or even within the introns, could still be responsible for the observed changing mRNA levels. To clarify the participation of transcriptional regulatory factors in the expression of Notch1 and DI/1 genes, their transcription rate was determined in neural precursors synchronized in either $\mathrm{M}$ or Sphase by means of quantitative real-time RT-PCR of the levels for their heterogeneous nuclear RNAs (hnRNA). This RNA species stands for the population of newly transcribed RNAs in the nuclei before they get processed as they come out from the nuclei into the cytoplasm. The measurement of this RNA species reflects the transcription rate since no other regulatory factors, such as the ones involved in mRNA stability, have yet come into contact with the RNA (Elferink and Reiners, 1996). Analysis of the hnRNA levels has revealed that transcriptional regulation is not involved in the changing expression levels of endogenous Notch1 and DI/1 during cell cycle progression, either in chick or mouse neural precursors, since hnRNA levels remain the same during M or Sphase (Cisneros et al., 2008).

The study of Notch1 and DI/1 mRNA stability in chick and mouse neural precursors by means of treatment with the transcription inhibitor actinomycin $D$ has revealed that both genes mRNA present less stability in S-phase when compared to their stability during $\mathrm{M}$ (Cisneros et al., 2008). This is not due to unspecific effects of the treatment, since the analysis of the stability of the $/ d 2$ gene rendered no changes in mRNA stability for this gene. Regulation of mRNA stability constitutes an essential mechanism of gene expression control, which allows the rapid response of cells to internal and external stimuli. The expression of certain genes involved in cell cycle regulation, such as cyclins A, B1 or D1 (Maity et al., 1995; Wang et al., 2000; Lal et al., 2004), or the CKI p21 Cip1 (Lal et al., 2004) is regulated by means of differential stability of their transcripts. As well, variations in the activity of the bHLH transcription factors Myod1 and myogenin, both involved in muscle development, are controlled by stability of their mRNAs (Figueroa et al., 2003). Surprisingly, the increased stability of Notch1 and DI/1 mRNAs during M contrasts with the general instability of transcripts observed during this cell-cycle phase, due to the hyperphosphorylation and the resultant reduction of the CDK1-dependent poly(A) polymerase activity (Colgan et al., 1996).

The mechanisms that regulate Notch1and DI/1mRNA stability in neural precursors are, at present, unknown. Nevertheless, it has been described that in Helobdella robusta the activity of p38MAPK stabilizes the zygotic Notch transcript (Gonsalves and Weisblat, 2007). This kinase induces cell-cycle arrest in $M$ under stress conditions (Takenaka et al., 1998) and it is active during M in rat retinal cells, where it has been shown to be necessary for 
normal cell cycle progression (Campos et al., 2002). Yet, its role during normal SNC development has to be clearly characterized, being a candidate as a regulator of Notch1 mRNA stability in neural precursors during $M$. Several elements located in mRNA sequences that promote the shortening of poly $(A)$ tails, and the thereafter transcript degradation, have been described. AU-rich elements (AREs) are located within the 3' UTR region of mRNAs and are defined by the sequence AUUUA (Beelman and Parker, 1995). These AREs sequences are responsible for regulating Notch mRNA stability in Helobdella robusta and their presence has been detected by in silico analysis within Notch and Delta transcripts sequences, as well as within $\angle f n g$, in all species where these regions have been described (Cisneros et al., 2008). Several RNA binding proteins interact with AREs sequences and regulate mRNA stability (Barreau et al., 2005). RNA-binding proteins such as the Elavl1 proteins and other protein family members are candidates in regulating Notch1 and D//1 stability in the neuroepithelium. Elavl1 belongs to the Embryonic Lethal Abnormal Vision (ELAV)-like family of RNA-binding proteins, which includes Elavl2, Elavl3 and Elavl4 proteins, and that can enhance cyclins A, B1 and D1mRNA stability (Wang et al., 2000; Lal et al., 2004), as well as the mRNAs for Myod and myogenin transcription factors (Figueroa et al., 2003). Although Elavl1 expression is ubiquitous, other type Elavl proteins are specifically expressed in neurons (Antic and Keene, 1997). In fact, the elav locus is essential for the development and maintenance of the Drosophila nervous system (Robinow et al., 1988). Another potential candidate for the regulation of neurogenic genes expression is the HNRNPD protein, an AREs-binding protein that favors cyclin D1 degradation (Lal et al., 2004).

Regulation of mRNA stability can also be achieved by means of microRNAs (miRNAs). miRNAs are small non-coding RNAs of 18-25 nucleotides in length that regulate gene expression at a

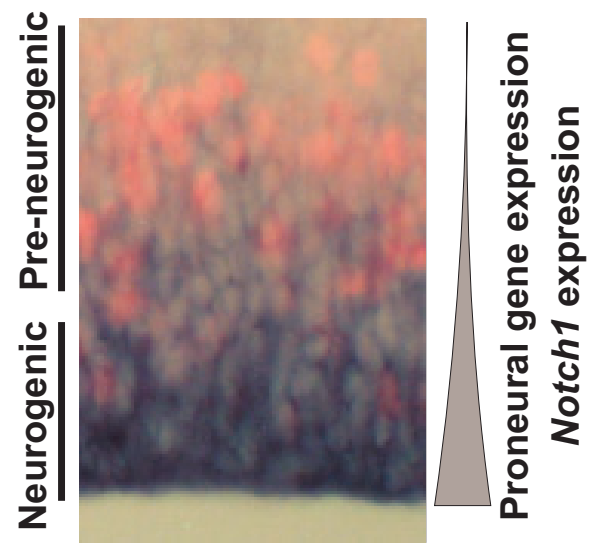

Fig. 4. Functional organization of the neuroepithelium in terms of its neurogenic potential. The orthogonal arrangement of the cells moving their nuclei up and down as they progress through the cell cycle (see Fig. 1) is translated into the segregation of the neuroepithelium into two zones, each comprising the soma of neural precursors that are transiently involved in distinct functions. In the apical region (neurogenic zone), proliferating cells are able to express Notch1 (dark blue), DII1, and the proneural determination gene Neurog2. In the basal epithelium (preneurogenic zone), neural precursors either cannot express these genes or express them at low levels, and they undergo S-phase as evidenced by a short pulse of BrdU (red). Apical surface down. post-translational level by binding to complementary sites in the mRNA of target genes (Lee et al., 1993; Wightman et al., 1993). The major regulatory function of miRNAs is to prevent protein translation from the target mRNA, although a decrease in mRNA stability is a function of some miRNAs (Behm-Ansmant et al., 2006). miRNAs provide a new level of gene expression regulation with an effect of fine-tuning tissue-specific gene expression. miRNAs are involved in multiple pathways in a variety of organisms, being the nervous system a rich source of miRNA expression (Krichevsky et al., 2003; Miska et al., 2004; Sempere et al., 2004). In fact, most miRNA data relevant to nervous system have focused on development, participating in processes of patterning and cell specification, although miRNA function has lately been related to neuronal plasticity and CNS-related diseases (for reviews, see Kosik, 2006; Fiore et al., 2008). Various miRNAs have already been proved to play a role in neurogenesis (Krichevsky et al., 2006), such as the Mirn200 family controlling olfactory neurogenesis. In fact, one of the identified targets for the Mirn200 family members is the LfngmRNA (Choi et al., 2008). A large number of miRNA have been predicted to target genes involved in cell fate decisions in the developing nervous system, in particular several miRNA target genes within components of the Notch pathway in Drosophila (Enright et al., 2003). As well, expression of many miRNAs has been detected during neural tube development in vertebrates (Darnell et al., 2006; Cao et al., 2007; Kapsimali et al., 2007; Wulczyn et al., 2007). Moreover, Notch1 mRNA itself has been described as a target gene for various miRNAs in a human neuroblastoma cell line (Fukuda et al., 2005), and Deltaexpression is regulated in Drosophilaby mir1 (Kwon et al., 2005). Furthermore, in silico analysis has yielded many murine miRNAs whose target genes can be both Notch1 and DI/1. Cell cycle dependant regulation of these genes may be mediated by miRNAs binding to their 3' UTR regions since it is already known that many important cell cycle molecules are target genes of various miRNAs (le Sage et al., 2007; Linsley et al., 2007; Ivanovska et al., 2008; Schultz et al., 2008). Moreover, miRNA regulation of translation is cell-cycle dependant, since it has been observed its strongest repressive potential in the $S$ and $\mathrm{S} / \mathrm{G} 2$ phases with minimal repression in the $\mathrm{G} 1$ phase (Vasudevan et al., 2008). Furthermore, miRNA activity can be affected by RNA-binding proteins (RBP). For instance, the RNA-binding protein Elavl1 associates with the 3' UTR region of the Trpv6 mRNA after stress, counteracting the effect of Mirn122a. Hence, there is a crucial role for RBP/miRNA interplay on 3' UTRs of mRNAs in developmental decisions (Kedde and Agami, 2008). Both factors, RBPs and miRNAs, may be responsible for the observed change in Notch 1 and D//1 mRNA stability and both are being taken into account in present studies intended to determine the mechanisms that regulate Notch 1 and D//1 gene expression.

\section{Neurogenesis and INM: functional regionalization of the neuroepithelium in apical neurogenic zone and basal pre- neurogenic zone}

In terms of neurogenesis, the differential expression through the cell cycle of the neurogenic genes DI/1 and Notch1, and the proneural gene Neurog2 suggests the segregation of the neuroepithelium into two zones. One region, correlating with neural precursors in S-phase, comprises a pre-neurogenic zone where the neural precursors present a diminished capacity to trigger 
A

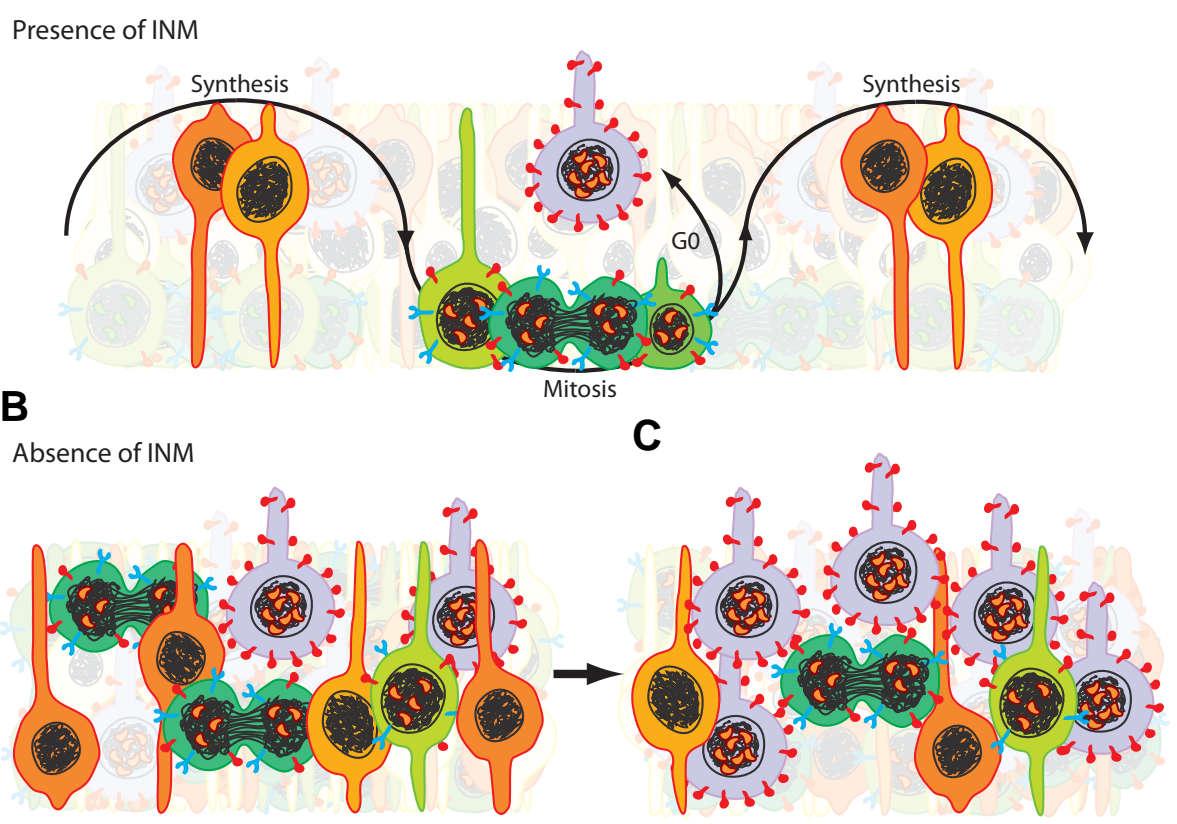

Fig. 5. Influence of INM in neurogenesis. (A) Due to the INM, neural precursors in neurogenic state (green) are grouped close to each other, while neural precursors in pre-neurogenic state (red) are segregated from the former ones. Delta-Notch signaling is maximal in neurogenic precursors, thus resulting in the production of a relatively low number of neurons (blue). (B) In the absence of INM, neurogenic and pre-neurogenic precursors are intermingled and DeltaNotch signaling becomes reduced (see green cells surrounded by red cells in left panel). This translates into an increase of neurogenesis and a depletion of neural precursors in the neuroepithelium (right panel).

inhibitory signals due to the lower expression levels of the previously mentioned genes. The second region, where proliferating neural precursors apically locate most of their soma during G2/M/ early G1 phases, constitutes the neurogenic zone, which is characterized by a high expression level of neurogenic and proneural determination genes (Murciano et al., 2002) (Fig. 4).

This model for the functional organization of the neuroepithelium due to the coordination between cell cycle and INM implies the local synchronization of neural precursors in relationship to their cell cycle stage and entails the grouping of cells with similar expression profiles of genes involved in neurogenesis. Hence, expression of Notch1 receptor and its activity modulator Lfng in cells undergoing $\mathrm{M}$, and located at the apical region, confers the capacity to respond to inhibitory signals from differentiating cells expressing DII1 ligand present in that region, as shown by induced expression of Notch effectors Hes 1 and Hes5 (Cisneros et al., 2008). Indeed, an apical process has been shown to be connected with the ventricular side of the neuroepithelium in postmitotic neuroblasts as they migrate out from the neuroepithelium (Minaki et al., 2005). This apical process is enriched in D/l1 mRNA, further stressing that the lateral inhibitory signals take place at the apical neuroepithelium. In this same apical zone is where expression of Neurog1 and Neurog 2 proneural genes greatly increases. Consequently to lateral inhibition, expression of proneural genes gets restricted to a few cells that enter the differentiation pathway and abandon the neuroepithelium. The cells that are not able to exit the cell cycle after the neurogenic stage, will keep cycling and will reduce the expression levels of neurogenic and proneural genes. Restricting the neurogenic capacity to a window prior to cell-cycle exit (G0) probably prevents the execution of the differentiation program during cell-cycle phases prior to $\mathrm{M}$.

In different animal species, neurogenesis is linked to synchronization waves prior to neuronal differentiation. Hence, in Drosophila embryo, neuroblasts production from neuroectoderm is preceded by cell-cycle arrest in G2 (Hartenstein et al., 1994). Similarly, in the eye imaginal disc of Drosophila has been observed synchronization in $\mathrm{G} 1$ of the photoreceptors precursors (Baker and Yu, 1997). Production of primary neurons in the anamniota neural plate, before it becomes a pseudostratified epithelium, is preceded by a $M$ synchronization wave that runs along the neural plate, starting from the most lateral end and moving towards the medial region (Hartenstein, 1989). These strategies are characterized by the presence of long periods of time during which neural precursors stay in interphase and there is no neuronal production. The existence of INM in vertebrate neuroepithelium may allow the continuous production of neurons from neural precursors in $\mathrm{G} 2 / \mathrm{M} / \mathrm{G} 1$, which transiently undergo a neurogenic state that has facilitated the vertebrate evolution towards more complex brains with greater number and types of neurons.

Relevance of neuroepithelium division into two regions, one neurogenic and another pre-neurogenic, is evident when INM is prevented (Fig. 5). In the absence of INM, the possibility of interactions between cells expressing neurogenic and proneural genes, and cells that are not capable to express these genes increases, therefore lateral inhibition signals diminish. This translates into greater neurogenesis with the consequent depletion of neural precursors, as seen in experiments with pharmacologic blocking of INM or computer modeling simulations (Murciano et al., 2002). Similarly, silencing Cep120 or Tacc3 in neural precursors during neocortical development impairs both INM and neural precursor cell proliferation, thus resulting in enhanced neuronal differentiation (Xie et al., 2007). Another piece of evidence supporting that the integrity of the three-dimensional structure of the neuroepithelium is crucial for the process of neurogenesis comes from the work by Bel-Vialar et al. (2007). These authors demonstrated that turning off Pax6 function, known to disturb INM (Tamai et al., 2007), provokes premature differentiation in the developing spinal cord. Alteration of INM in the retina of dynactin1 mutant zebrafish triggers enhanced retinal ganglion cell production (Del Bene et al., 2008), as previously shown in the chick retina by Murciano et al. (2002). Importantly, NICD expression or her4 disruption in the mutant zebrafish embryos suppressed neuronal overproduction (Del Bene et al., 2008), further indicating that enhanced neurogenesis in the absence of INM is due to reduced Notch signaling.

One important question currently under debate regards to the 
putative retraction of the basal process once a neural precursor becomes rounded during $\mathrm{M}$. Indeed, retraction of this basal process would prevent mitotic cells from receiving lateral inhibitory signals from the DII1-positive postmitotic neuroblasts that are located at the basal neuroepithelium as they migrate towards the differentiated zone. For quite long time it was believed that the basal process of each neural precursor is lost during cell division (Hinds and Ruffett, 1971; Berry and Johnson, 1975). However, other authors have challenged this view and presented evidence that a extremely thin basal process composed of membrane and lacking microtubules (Wilcock et al., 2007) is retained by the neural precursors undergoing $\mathrm{M}$ and it is inherited by one of the daughter cells (Miyata et al., 2001; Noctor et al., 2002; Das et al., 2003; Afonso and Henrique, 2006), but whether this is the case for all neural precursors is currently unclear. In this regard, a detailed analysis performed by Saito et al. (2003) in mouse retina slices demonstrated a reduced capacity to extend basal processes in those daughter cells that do not inherit these structures during $\mathrm{M}$. These cells show short basal processes of approximately $20 \mu \mathrm{m}$, which do not reach the basal neuroepithelium. In line with these results, a recent study by Pearson et al. (2005) demonstrates the absence of basal process in some mitotic neural precursors. The reduced capacity of certain neural precursors to move their nuclei to the basal neuroepithelium has been also reported by Baye and Link (2007) in the zebrafish retina.

The proposed arrangement of the vertebrate neuroepithelium seems to be restricted to neural tube areas where neurons are been produced. In the caudal neural plate, there is a population of stem cells that give rise to the spinal cord. In this region, D//1 is expressed in cycling cells in a cell cycle independent manner and Notch is constantly active (Akai et al., 2005). In this context, uniform expression of D//1 translates into mutual inhibition of all cells in the neural plate, preventing neuronal differentiation. When cells abandon this region, they initially maintain D//1expression in neural precursors undergoing S-phase (Hammerle and Tejedor, 2007), and subsequently lateral inhibition gets activated and D//1 expression is restricted to cells undergoing neuronal differentiation (Mizuhara et al., 2005). Finally, the cumulative data suggest that differential expression of neurogenic genes during cell cycle and its spatial localization along the apical-basal axis of the neuroepithelium are extremely important for the precise differentiation of neural precursors.

\section{Response ability to environmental factors during cell cycle}

In the nervous system of almost all species, there is a correlation between the phenotype a neuron adopts and its birth time (Caviness and Sidman, 1973). Different cell fates could be determined when cells are actively proliferating, near their final cell cycle, or post-mitotically. Studies in Drosophila (Isshiki et al., 2001), zebrafish (Kay et al., 2001) and Xenopus (Ohnuma et al., 2002), indicate that distinct neural fates may be determined during the final cell cycle of neural precursors and, moreover, correct formation of nervous system depends on coordination between cell cycle regulation and cell fate determination.

Neural precursors response to extrinsic cues differs along cell cycle. Thus, neural precursors from mouse or ferret cortex (McConnell and Kaznowski, 1991; Fukumitsu et al., 2006) or rat retina (Belliveau and Cepko, 1999) receive determination signals during S-phase but not during G2, M or G1. Motor neuron generation depends on two critical periods of Shh signaling: an early period during which naive neural plate cells are converted into ventralized neural precursors and a late period that extends well into S-phase of the final neural precursor cell division, during which Shh drives the differentiation of ventralized neural precursors into motor neurons (Ericson et al., 1996). Regarding Caenorhabditis elegans, vulva precursor cells adopt different fates in response to lin-12 lateral signaling fate accordingly with their cell cycle phase. Coupling developmental decisions to cell cycle transitions may provide a mechanism for prioritizing or ordering choices of cell fates for multipotential cells (Ambros, 1999). Lack of neurogenic capacity in vertebrate neural precursors during S-phase could facilitate this process.

\section{Acknowledgments}

This work was supported by the Ministerio de Ciencia y Tecnología (BCM2003-03441/BFU2006-00805), Fundación "La Caixa" (BM05-71O), and FUNDALUCE.

\section{References}

AFONSO, C. and HENRIQUE, D. (2006). PAR3 acts as a molecular organizer to define the apical domain of chick neuroepithelial cells. J Cell Sci 119: 42934304.

AKAI, J., HALLEY, P.A. and STOREY, K.G. (2005). FGF-dependent Notch signaling maintains the spinal cord stem zone. Genes Dev 19: 2877-2887.

AMBROS, V. (1999). Cell cycle-dependent sequencing of cell fate decisions in Caenorhabditis elegans vulva precursor cells. Development 126: 1947-1956.

ANDREAZZOLI, M., GESTRI, G., ANGELONI, D., MENNA, E. and BARSACCHI, G. (1999). Role of Xrx1 in Xenopus eye and anterior brain development. Development 126: 2451-2460.

ANTIC, D. and KEENE, J.D. (1997). Embryonic lethal abnormal visual RNA-binding proteins involved in growth, differentiation, and posttranscriptional gene expression. Am J Hum Genet 61: 273-278.

ARTAVANIS-TSAKONAS, S., RAND, M.D. and LAKE, R.J. (1999). Notch signaling: cell fate control and signal integration in development. Science 284: 770776.

ASTROM, K.E. and WEBSTER, H.D. (1991). The early development of the neopallial wall and area choroidea in fetal rats. A light and electron microscopic study. Adv Anat Embryol Cell Biol123: 1-76.

BADENHORST, P. (2001). Tramtrack controls glial number and identity in the Drosophila embryonic CNS. Development 128: 4093-4101.

BAEK, S.H., KIOUSSI, C., BRIATA, P., WANG, D., NGUYEN, H.D., OHGI, K.A., GLASS, C.K., WYNSHAW-BORIS, A., ROSE, D.W. and ROSENFELD, M.G. (2003). Regulated subset of G1 growth-control genes in response to derepression by the Wnt pathway. Proc Natl Acad Sci USA 100: 3245-3250.

BAKER, N.E. and YU, S.Y. (1997). Proneural function of neurogenic genes in the developing Drosophila eye. Curr Bio/7: 122-132.

BARREAU, C., PAILLARD, L. and OSBORNE, H.B. (2005). AU-rich elements and associated factors: are there unifying principles? Nucleic Acids Res 33: 71387150 .

BAYE, L.M. and LINK, B.A. (2007). Interkinetic nuclear migration and the selection of neurogenic cell divisions during vertebrate retinogenesis. J Neurosci 27: 10143-10152.

BAYE, L.M. and LINK, B.A. (2008). Nuclear migration during retinal development. Brain Res 1192: 29-36.

BECKERS, J., CARON, A., HRABE DE ANGELIS, M., HANS, S., CAMPOS ORTEGA, J.A. and GOSSLER, A. (2000). Distinct regulatory elements direct delta1 expression in the nervous system and paraxial mesoderm of transgenic mice. Mech Dev 95: 23-34.

BEELMAN, C.A. and PARKER, R. (1995). Degradation of mRNA in eukaryotes. Cel/ 81: 179-183.

BEHM-ANSMANT, I., REHWINKEL, J. and IZAURRALDE, E. (2006). MicroRNAs 
silence gene expression by repressing protein expression and/or by promoting mRNA decay. Cold Spring Harb Symp Quant Biol71: 523-530.

BEL-VIALAR, S., MEDEVIELLE, F. and PITUELLO, F. (2007). The on/off of Pax6 controls the tempo of neuronal differentiation in the developing spinal cord. Dev Bio/305: 659-673.

BELLIVEAU, M.J. and CEPKO, C.L. (1999). Extrinsic and intrinsic factors control the genesis of amacrine and cone cells in the rat retina. Development 126: 555566.

BERRY, S.J. and JOHNSON, E. (1975). Formation of temporary flagellar structures during insect organogenesis. J Cell Bio/65: 489-492.

BERTRAND, N., CASTRO, D.S. and GUILLEMOT, F. (2002). Proneural genes and the specification of neural cell types. Nat Rev Neurosci3: 517-530.

BRAY, S.J. (2006). Notch signalling: a simple pathway becomes complex. Nat Rev $\mathrm{Mol} \mathrm{Ce} / \mathrm{BiO}$ /7: 678-689.

CAMPOS, C.B., BEDARD, P.A. and LINDEN, R. (2002). Activation of p38 mitogenactivated protein kinase during normal mitosis in the developing retina. Neuroscience 112: 583-591.

CAMPUZANO, S. and MODOLELL, J. (1992). Patterning of the Drosophilanervous system: the achaete-scute gene complex. Trends Genet 8: 202-208.

CANTON, D.A. and LITCHFIELD, D.W. (2006). The shape of things to come: an emerging role for protein kinase CK2 in the regulation of cell morphology and the cytoskeleton. Cell Signa/18: 267-275.

CAO, X., PFAFF, S.L. and GAGE, F.H. (2007). A functional study of miR-124 in the developing neural tube. Genes Dev21: 531-536.

CARNEIRO, A.C., FRAGEL-MADEIRA, L., SILVA-NETO, M.A. and LINDEN, R. (2008). A role for CK2 upon interkinetic nuclear migration in the cell cycle of retinal progenitor cells. Dev Neurobio/68: 620-631.

CASTRO, D.S., SKOWRONSKA-KRAWCZYK, D., ARMANT, O., DONALDSON, I.J., PARRAS, C., HUNT, C., CRITCHLEY, J.A., NGUYEN, L., GOSSLER, A., GOTTGENS, B. et al. (2006). Proneural bHLH and Brn proteins coregulate a neurogenic program through cooperative binding to a conserved DNA motif. Dev Cel/11: 831-844.

CAVINESS, V.S., JR. and SIDMAN, R.L. (1973). Time of origin or corresponding cell classes in the cerebral cortex of normal and reeler mutant mice: an autoradiographic analysis. J Comp Neuro/148: 141-151.

CISNEROS, E., LATASA, M.J., GARCIA-FLORES, M. and FRADE, J.M. (2008). Instability of Notch1 and Delta1 mRNAs and reduced Notch activity in vertebrate neuroepithelial cells undergoing S-phase. Mol Cell Neurosci37: 820-831.

COLGAN, D.F., MURTHY, K.G., PRIVES, C. and MANLEY, J.L. (1996). Cell-cycle related regulation of poly $(A)$ polymerase by phosphorylation. Nature $384: 282$ 285.

CULI, J. and MODOLELL, J. (1998). Proneural gene self-stimulation in neura precursors: an essential mechanism for sense organ development that is regulated by Notch signaling. Genes Dev 12: 2036-2047.

CHENN, A., ZHANG, Y.A., CHANG, B.T. and MCCONNELL, S.K. (1998). Intrinsic polarity of mammalian neuroepithelial cells. Mol Cell Neurosci11: 183-193.

CHOI, P.S., ZAKHARY, L., CHOI, W.Y., CARON, S., ALVAREZ-SAAVEDRA, E., MISKA, E.A., MCMANUS, M., HARFE, B., GIRALDEZ, A.J., HORVITZ, R.H. et al. (2008). Members of the miRNA-200 family regulate olfactory neurogenesis. Neuron 57: 41-55.

DARNELL, D.K., KAUR, S., STANISLAW, S., KONIECZKA, J.H., YATSKIEVYCH, T.A. and ANTIN, P.B. (2006). MicroRNA expression during chick embryo development. Dev Dyn 235: 3156-3165.

DAS, T., PAYER, B., CAYOUETTE, M. and HARRIS, W.A. (2003). In vivo timelapse imaging of cell divisions during neurogenesis in the developing zebrafish retina. Neuron 37: 597-609.

DAUDET, N. and LEWIS, J. (2005). Two contrasting roles for Notch activity in chick inner ear development: specification of prosensory patches and lateral inhibition of hair-cell differentiation. Development 132: 541-551.

DAVIS, R.L. and TURNER, D.L. (2001). Vertebrate hairy and Enhancer of split related proteins: transcriptional repressors regulating cellular differentiation and embryonic patterning. Oncogene 20: 8342-8357.

DE LA POMPA, J.L., WAKEHAM, A., CORREIA, K.M., SAMPER, E., BROWN, S., AGUILERA, R.J., NAKANO, T., HONJO, T., MAK, T.W., ROSSANT, J. et al. (1997). Conservation of the Notch signalling pathway in mammalian neurogenesis. Development 124: 1139-1148.

DEL BENE, F., WEHMAN, A.M., LINK, B.A. and BAIER, H. (2008). Regulation of neurogenesis by interkinetic nuclear migration through an apical-basal notch gradient. Cel/134: 1055-1065.

DEL MONTE, G., GREGO-BESSA, J., GONZALEZ-RAJAL, A., BOLOS, V. and DE LA POMPA, J.L. (2007). Monitoring Notch1 activity in development: evidence for a feedback regulatory loop. Dev Dyn 236: 2594-2614.

DYER, M.A., LIVESEY, F.J., CEPKO, C.L. and OLIVER, G. (2003). Prox1 function controls progenitor cell proliferation and horizontal cell genesis in the mammalian retina. Nat Genet 34: 53-58

ELFERINK, C.J. and REINERS, J.J., JR. (1996). Quantitative RT-PCR on CYP1A1 heterogeneous nuclear RNA: a surrogate for the in vitro transcription run-on assay. Biotechniques 20: 470-477.

ENRIGHT, A.J., JOHN, B., GAUL, U., TUSCHL, T., SANDER, C. and MARKS, D.S (2003). MicroRNA targets in Drosophila. Genome Bio/5: R1.

ERICSON, J., MORTON, S., KAWAKAMI, A., ROELINK, H. and JESSELL, T.M. (1996). Two critical periods of Sonic Hedgehog signaling required for the specification of motor neuron identity. Ce//87: 661-673.

FARAH, M.H., OLSON, J.M., SUCIC, H.B., HUME, R.I., TAPSCOTT, S.J. and TURNER, D.L. (2000). Generation of neurons by transient expression of neural bHLH proteins in mammalian cells. Development 127: 693-702.

FERREIRO, B., KINTNER, C., ZIMMERMAN, K., ANDERSON, D. and HARRIS W.A. (1994). XASH genes promote neurogenesis in Xenopus embryos. Development 120: 3649-3655.

FIGUEROA, A., CUADRADO, A., FAN, J., ATASOY, U., MUSCAT, G.E., MUNOZCANOVES, P., GOROSPE, M. and MUNOZ, A. (2003). Role of HuR in skeletal myogenesis through coordinate regulation of muscle differentiation genes. Mol Cell Bio/23: 4991-5004.

FIOR, R. and HENRIQUE, D. (2005). A novel hes5/hes6 circuitry of negative regulation controls Notch activity during neurogenesis. Dev Bio/281: 318-333.

FIORE, R., SIEGEL, G. and SCHRATT, G. (2008). MicroRNA function in neuronal development, plasticity and disease. Biochim Biophys Acta. 1779: 471-478

FRADE, J.M. (2002). Interkinetic nuclear movement in the vertebrate neuroepithelium: encounters with an old acquaintance. Prog Brain Res 136: 67-71.

FRADE, J.M., BOVOLENTA, P. and RODRIGUEZ-TEBAR, A. (1999). Neurotrophins and other growth factors in the generation of retinal neurons. Microsc Res Tech 45: 243-251.

FUJITA, S. (1962). Kinetics of cellular proliferation. Exp Cell Res 28: 52-60.

FUKUDA, Y., KAWASAKI, H. and TAIRA, K. (2005). Exploration of human miRNA target genes in neuronal differentiation. Nucleic Acids Symp Ser (Oxf)341-342.

FUKUMITSU, H., OHTSUKA, M., MURAI, R., NAKAMURA, H., ITOH, K. and FURUKAWA, S. (2006). Brain-derived neurotrophic factor participates in determination of neuronal laminar fate in the developing mouse cerebral cortex. $J$ Neurosci26: 13218-13230.

GAMBELLO, M.J., DARLING, D.L., YINGLING, J., TANAKA, T., GLEESON, J.G. and WYNSHAW-BORIS, A. (2003). Multiple dose-dependent effects of Lis1 on cerebral cortical development. J Neurosci23: 1719-1729.

GONSALVES, F.C. and WEISBLAT, D.A. (2007). MAPK regulation of maternal and zygotic Notch transcript stability in early development. Proc Nat/ Acad Sci USA 104: 531-6.

GOTZ, M. and HUTTNER, W.B. (2005). The cell biology of neurogenesis. Nat Rev Mol Cell Bio/6: 777-788.

GRANA, X. and REDDY, E.P. (1995). Cell cycle control in mammalian cells: role of cyclins, cyclin dependent kinases (CDKs), growth suppressor genes and cyclindependent kinase inhibitors (CKIs). Oncogene 11: 211-219.

GUI, H., LI, S. and MATISE, M.P. (2007). A cell-autonomous requirement for Cip/ Kip cyclin-kinase inhibitors in regulating neuronal cell cycle exit but not differentiation in the developing spinal cord. Dev Bio/301: 14-26.

GUILLEMOT, F., LO, L.C., JOHNSON, J.E., AUERBACH, A., ANDERSON, D.J. and JOYNER, A.L. (1993). Mammalian achaete-scute homolog 1 is required for the early development of olfactory and autonomic neurons. Cel/75: 463-476.

HAINES, N. and IRVINE, K.D. (2003). Glycosylation regulates Notch signalling. Nat Rev Mol Cell Biol4: 786-797.

HAMMERLE, B. and TEJEDOR, F.J. (2007). A novel function of DELTA-NOTCH 
signalling mediates the transition from proliferation to neurogenesis in neural progenitor cells. PLOS ONE2: e1169.

HAMMERLE, B., VERA-SAMPER, E., SPEICHER, S., ARENCIBIA, R., MARTINEZ, S. and TEJEDOR, F.J. (2002). Mnb/Dyrk1A is transiently expressed and asymmetrically segregated in neural progenitor cells at the transition to neurogenic divisions. Dev Bio/246: 259-273.

HARPER, J.W. (2002). A phosphorylation-driven ubiquitination switch for cell-cycle control. Trends Cell Bio/ 12: 104-107.

HARTENSTEIN, V. (1989). Early neurogenesis in Xenopus. the spatio-temporal pattern of proliferation and cell lineages in the embryonic spinal cord. Neuron 3: 399-411.

HARTENSTEIN, V., TEPASS, U. and GRUSZYNSKI-DEFEO, E. (1994). Embryonic development of the stomatogastric nervous system in Drosophila. J Comp Neuro/350: 367-381.

HASSAN, B.A. and BELLEN, H.J. (2000). Doing the MATH: is the mouse a good model for fly development? Genes Dev 14: 1852-1865.

HAYES, N.L. and NOWAKOWSKI, R.S. (2000). Exploiting the dynamics of S-phase tracers in developing brain: interkinetic nuclear migration for cells entering versus leaving the S-phase. Dev Neurosci22: 44-55.

HEINS, N., CREMISI, F., MALATESTA, P., GANGEMI, R.M., CORTE, G., PRICE, J., GOUDREAU, G., GRUSS, P. and GOTZ, M. (2001). Emx2 promotes symmetric cell divisions and a multipotential fate in precursors from the cerebral cortex. Mol Cell Neurosci 18: 485-502.

HEITZLER, P., BOUROUIS, M., RUEL, L., CARTERET, C. and SIMPSON, P. (1996). Genes of the Enhancer of split and achaete-scute complexes are required for a regulatory loop between Notch and Delta during lateral signalling in Drosophila. Development 122: 161-171.

HENRIQUE, D., ADAM, J., MYAT, A., CHITNIS, A., LEWIS, J. and ISH-HOROWICZ, D. (1995). Expression of a Delta homologue in prospective neurons in the chick. Nature 375: 787-790.

HENRIQUE, D., HIRSINGER, E., ADAM, J., LE ROUX, I., POURQUIE, O., ISHHOROWICZ, D. and LEWIS, J. (1997). Maintenance of neuroepithelial progenitor cells by Delta-Notch signalling in the embryonic chick retina. Curr Bio/7: 661670.

HINDS, J.W. and RUFFETT, T.L. (1971). Cell proliferation in the neural tube: an electron microscopic and golgi analysis in the mouse cerebral vesicle. $Z$ Zellforsch Mikrosk Anat 115: 226-264.

ISSHIKI, T., PEARSON, B., HOLBROOK, S. and DOE, C.Q. (2001). Drosophila neuroblasts sequentially express transcription factors which specify the temporal identity of their neuronal progeny. Cel/106: 511-521.

IVANOVSKA, I., BALL, A.S., DIAZ, R.L., MAGNUS, J.F., KIBUKAWA, M., SCHELTER, J.M., KOBAYASHI, S.V., LIM, L., BURCHARD, J., JACKSON, A.L. et al. (2008). MicroRNAs in the miR-106b family regulate p21/CDKN1A and promote cell cycle progression. Mo/ Cel/ Bio/28: 2167-2174.

JIMENEZ, F. and MODOLELL, J. (1993). Neural fate specification in Drosophila. Curr Opin Genet Dev 3: 626-632.

JOHNSTON, L.A. and EDGAR, B.A. (1998). Wingless and Notch regulate cell-cycle arrest in the developing Drosophila wing. Nature 394: 82-84.

KAPSIMALI, M., KLOOSTERMAN, W.P., DE BRUIJN, E., ROSA, F., PLASTERK, R.H. and WILSON, S.W. (2007). MicroRNAs show a wide diversity of expression profiles in the developing and mature central nervous system. Genome Biol 8: R173.

KARFUNKEL, P. (1972). The activity of microtubules and microfilaments in neurulation in the chick. J Exp Zoo/181: 289-301.

KAY, J.N., FINGER-BAIER, K.C., ROESER, T., STAUB, W. and BAIER, H. (2001). Retinal ganglion cell genesis requires lakritz, a Zebrafish atonal Homolog. Neuron 30: 725-736.

KEDDE, M. and AGAMI, R. (2008). Interplay between microRNAs and RNA-binding proteins determines developmental processes. Cell Cycle 7: 899-903.

KENNEY, A.M., COLE, M.D. and ROWITCH, D.H. (2003). Nmyc upregulation by sonic hedgehog signaling promotes proliferation in developing cerebellar granule neuron precursors. Development 130: 15-28.

KIM, A.H. and BONNI, A. (2007). Thinking within the D box: initial identification of Cdh1-APC substrates in the nervous system. Mol Cel/ Neurosci34: 281-287.

KINTNER, C. (2002). Neurogenesis in embryos and in adult neural stem cells. $J$
Neurosci22: 639-643.

KIOUSSI, C., BRIATA, P., BAEK, S.H., ROSE, D.W., HAMBLET, N.S., HERMAN, T., OHGI, K.A., LIN, C., GLEIBERMAN, A., WANG, J. etal. (2002). Identification of a Wnt/Dvl/beta-Catenin $\rightarrow$ Pitx2 pathway mediating cell-type-specific proliferation during development. Ce//111: 673-685.

KOBAYASHI, M., NISHIKAWA, K., SUZUKI, T. and YAMAMOTO, M. (2001). The homeobox protein Six3 interacts with the Groucho corepressor and acts as a transcriptional repressor in eye and forebrain formation. Dev Bio/232: 315-326.

KOSIK, K.S. (2006). The neuronal microRNA system. Nat Rev NeurosC17: 911-920.

KRICHEVSKY, A.M., KING, K.S., DONAHUE, C.P., KHRAPKO, K. and KOSIK, K.S. (2003). A microRNA array reveals extensive regulation of microRNAs during brain development. RNA 9: 1274-1281.

KRICHEVSKY, A.M., SONNTAG, K.C., ISACSON, O. and KOSIK, K.S. (2006) Specific microRNAs modulate embryonic stem cell-derived neurogenesis. Stem Cells 24: 857-864

KUNISCH, M., HAENLIN, M. and CAMPOS-ORTEGA, J.A. (1994). Lateral inhibition mediated by the Drosophilaneurogenic gene delta is enhanced by proneural proteins. Proc Nat/ Acad Sci USA 91: 10139-10143.

KWON, C., HAN, Z., OLSON, E.N. and SRIVASTAVA, D. (2005). MicroRNA1 influences cardiac differentiation in Drosophila and regulates Notch signaling. Proc Natl Acad Sci USA 102: 18986-18991.

LAL, A., MAZAN-MAMCZARZ, K., KAWAI, T., YANG, X., MARTINDALE, J.L. and GOROSPE, M. (2004). Concurrent versus individual binding of HuR and AUF1 to common labile target mRNAs. EMBO J23: 3092-3102.

LE SAGE, C., NAGEL, R. and AGAMI, R. (2007). Diverse ways to control p27Kip1 function: miRNAs come into play. Cel/ Cycle 6: 2742-2749.

LEE, R.C., FEINBAUM, R.L. and AMBROS, V. (1993). The C. elegans heterochronic gene lin-4 encodes small RNAs with antisense complementarity to lin-14. Cell 75: 843-854

LEES, E. (1995). Cyclin dependent kinase regulation. Curr Opin Cel/ Bio/7: 773 780.

LI, X., PERISSI, V., LIU, F., ROSE, D.W. and ROSENFELD, M.G. (2002). Tissuespecific regulation of retinal and pituitary precursor cell proliferation. Science 297: $1180-1183$

LINDSELL, C.E., BOULTER, J., DISIBIO, G., GOSSLER, A. and WEINMASTER, G. (1996). Expression patterns of Jagged, Delta1, Notch1, Notch2, and Notch3 genes identify ligand-receptor pairs that may function in neural development. Mol Cell Neurosci 8: 14-27.

LINSLEY, P.S., SCHELTER, J., BURCHARD, J., KIBUKAWA, M., MARTIN, M.M., BARTZ, S.R., JOHNSON, J.M., CUMMINS, J.M., RAYMOND, C.K., DAl, H. et al. (2007). Transcripts targeted by the microRNA-16 family cooperatively regulate cell cycle progression. Mol Cell Bio/27: 2240-2252.

LOBJOIS, V., BENAZERAF, B., BERTRAND, N., MEDEVIELLE, F. and PITUELLO, F. (2004). Specific regulation of cyclins D1 and D2 by FGF and Shh signaling coordinates cell cycle progression, patterning, and differentiation during early steps of spinal cord development. Dev Bio/273: 195-209.

LOPEZ-RIOS, J., TESSMAR, K., LOOSLI, F., WITTBRODT, J. and BOVOLENTA P. (2003). Six 3 and Six 6 activity is modulated by members of the groucho family. Development 130: 185-195.

LOWELL, S., BENCHOUA, A., HEAVEY, B. and SMITH, A.G. (2006). Notch promotes neural lineage entry by pluripotent embryonic stem cells. PLOS Biol 4: e121.

MA, Q., KINTNER, C. and ANDERSON, D.J. (1996). Identification of neurogenin, a vertebrate neuronal determination gene. Cel/ 87: 43-52.

MAITY, A., MCKENNA, W.G. and MUSCHEL, R.J. (1995). Evidence for posttranscriptional regulation of cyclin B1 mRNA in the cell cycle and following irradiation in HeLa cells. EMBO J14: 603-609.

MASSARI, M.E. and MURRE, C. (2000). Helix-loop-helix proteins: regulators of transcription in eucaryotic organisms. Mol Cell Bio/20: 429-440.

MCCONNELL, S.K. and KAZNOWSKI, C.E. (1991). Cell cycle dependence of laminar determination in developing neocortex. Science 254: 282-285.

MCCORMICK, M.B., TAMIMI, R.M., SNIDER, L., ASAKURA, A., BERGSTROM, D. and TAPSCOTT, S.J. (1996). NeuroD2 and neuroD3: distinct expression patterns and transcriptional activation potentials within the neuroD gene family. Mol Cell Biol 16: 5792-5800. 
MESSIER, P.M. and AUCLAIR, C. (1977). Alteration of apical junctions and inhibition of interkinetic nuclear migration by cytochalasin B and trypsin. Acta Embryol Exp (Palermo) 341-356.

MEYER, D.K. (2006). The effects of PACAP on neural cell proliferation. Regul Pept 137: $50-57$

MINAKI, Y., MIZUHARA, E., MORIMOTO, K., NAKATANI, T., SAKAMOTO, Y., INOUE, Y., SATOH, K., IMAI, T., TAKAI, Y. and ONO, Y. (2005). Migrating postmitotic neural precursor cells in the ventricular zone extend apical processes and form adherens junctions near the ventricle in the developing spinal cord. Neurosci Res 52: 250-262.

MISKA, E.A., ALVAREZ-SAAVEDRA, E., TOWNSEND, M., YOSHII, A., SESTAN, N., RAKIC, P., CONSTANTINE-PATON, M. and HORVITZ, H.R. (2004). Microarray analysis of microRNA expression in the developing mammalian brain. Genome Bio/5: R68.

MIYATA, T. (2008). Development of three-dimensional architecture of the neuroepithelium: role of pseudostratification and cellular 'community'. Dev Growth Differ 50 Suppl 1: S105-S112.

MIYATA, T., KAWAGUCHI, A., OKANO, H. and OGAWA, M. (2001). Asymmetric inheritance of radial glial fibers by cortical neurons. Neuron 31: 727-741.

MIZUHARA, E., NAKATANI, T., MINAKI, Y., SAKAMOTO, Y., ONO, Y. and TAKAI, Y. (2005). MAGI1 recruits DIl1 to cadherin-based adherens junctions and stabilizes it on the cell surface. J Biol Chem 280: 26499-26507.

MORALES, A.V., YASUDA, Y. and ISH-HOROWICZ, D. (2002). Periodic Lunatic fringe expression is controlled during segmentation by a cyclic transcriptional enhancer responsive to notch signaling. Dev Cel/3: 63-74

MORGAN, D.O. (1997). Cyclin-dependent kinases: engines, clocks, and microprocessors. Annu Rev Cell Dev Biol 13: 261-291.

MURCIANO, A., ZAMORA, J., LOPEZ-SANCHEZ, J. and FRADE, J.M. (2002). Interkinetic nuclear movement may provide spatial clues to the regulation of neurogenesis. Mol Cell Neurosci21: 285-300.

MURRAY, A. and HUNT, T. (1993). The Cell Cycle: An Introduction. Oxford University Press, New York.

MYAT, A., HENRIQUE, D., ISH-HOROWICZ, D. and LEWIS, J. (1996). A chick homologue of Serrate and its relationship with Notch and Delta homologues during central neurogenesis. Dev Bio/174: 233-247.

NARDELLI, J., CATALA, M. and CHARNAY, P. (2003). Establishment of embryonic neuroepithelial cell lines exhibiting an epiplastic expression pattern of region specific markers. J Neurosci Res 73: 737-752.

NELSON, B.R., GUMUSCU, B., HARTMAN, B.H. and REH, T.A. (2006). Notch activity is downregulated just prior to retinal ganglion cell differentiation. Dev Neurosci28: 128-141.

NOCTOR, S.C., FLINT, A.C., WEISSMAN, T.A., WONG, W.S., CLINTON, B.K. and KRIEGSTEIN, A.R. (2002). Dividing precursor cells of the embryonic cortical ventricular zone have morphological and molecular characteristics of radial glia. JNeurosci22: 3161-3173.

OHNUMA, S., HOPPER, S., WANG, K.C., PHILPOTT, A. and HARRIS, W.A. (2002). Co-ordinating retinal histogenesis: early cell cycle exit enhances early cell fate determination in the Xenopus retina. Development 129: 2435-2446.

OHNUMA, S., PHILPOTT, A. and HARRIS, W.A. (2001). Cell cycle and cell fate in the nervous system. Curr Opin Neurobio/11: 66-73.

OLIVER, T.G., GRASFEDER, L.L., CARROLL, A.L., KAISER, C., GILLINGHAM, C.L., LIN, S.M., WICKRAMASINGHE, R., SCOTT, M.P. and WECHSLERREYA, R.J. (2003). Transcriptional profiling of the Sonic hedgehog response: a critical role for $\mathrm{N}$-myc in proliferation of neuronal precursors. Proc Nat/ Acad Sci USA 100: 7331-7336.

PEARSON, R.A., CATSICAS, M., BECKER, D.L., BAYLEY, P., LUNEBORG, N.L. and MOBBS, P. (2004). $\mathrm{Ca}(2+)$ signalling and gap junction coupling within and between pigment epithelium and neural retina in the developing chick. Eur $J$ Neurosci 19: 2435-2445.

PEARSON, R.A., LUNEBORG, N.L., BECKER, D.L. and MOBBS, P. (2005). Gap junctions modulate interkinetic nuclear movement in retinal progenitor cells. $J$ Neurosci25: 10803-10814

PETERS, J.M. (2002). The anaphase-promoting complex: proteolysis in mitosis and beyond. $\mathrm{Mo} / \mathrm{Ce} / / 9$ : 931-943.

RATINEAU, C., PETRY, M.W., MUTOH, H. and LEITER, A.B. (2002). Cyclin D1 represses the basic helix-loop-helix transcription factor, BETA2/NeuroD. J Biol Chem 277: 8847-8853.

REINSCH, S. and GONCZY, P. (1998). Mechanisms of nuclear positioning. J Cell Sci111 (Pt 16): 2283-2295.

ROBINOW, S., CAMPOS, A.R., YAO, K.M. and WHITE, K. (1988). The elav gene product of Drosophila, required in neurons, has three RNP consensus motifs. Science 242: 1570-1572.

SAITO, K., KAWAGUCHI, A., KASHIWAGI, S., YASUGI, S., OGAWA, M. and MIYATA, T. (2003). Morphological asymmetry in dividing retinal progenitor cells. Dev Growth Differ 45: 219-229.

SAUER, F.C. (1935). Mitosis in the neural tube. J Comp Neuro/62: 377-405.

SAUER, M.E. and WALKER, B.E. (1959). Radioautographic study of interkinetic nuclear migration in the neural tube. Proc Soc Exp Biol Med 101: 557-560.

SCHROER, T.A. (2004). Dynactin. Annu Rev Cell Dev Biol20: 759-779.

SCHULTZ, J., LORENZ, P., GROSS, G., IBRAHIM, S. and KUNZ, M. (2008). MicroRNA let-7b targets important cell cycle molecules in malignant melanoma cells and interferes with anchorage-independent growth. Cel/ Res 18: 549-557.

SEMPERE, L.F., FREEMANTLE, S., PITHA-ROWE, I., MOSS, E., DMITROVSKY, E. and AMBROS, V. (2004). Expression profiling of mammalian microRNAs uncovers a subset of brain-expressed microRNAs with possible roles in murine and human neuronal differentiation. Genome Bio/5: R13.

SEO, S. and KROLL, K.L. (2006). Geminin's double life: chromatin connections that regulate transcription at the transition from proliferation to differentiation. Cell Cycle 5: 374-379

SHERR, C.J. (1994). G1 phase progression: cycling on cue. Cel/79: 551-555.

SHERR, C.J., KATO, J., QUELLE, D.E., MATSUOKA, M. and ROUSSEL, M.F. (1994). D-type cyclins and their cyclin-dependent kinases: G1 phase integrators of the mitogenic response. Cold Spring Harb Symp Quant Bio/59: 11-19.

SHERR, C.J. and ROBERTS, J.M. (1999). CDK inhibitors: positive and negative regulators of G1-phase progression. Genes Dev13: 1501-1512.

SHIMOJO, H., OHTSUKA, T. and KAGEYAMA, R. (2008). Oscillations in notch signaling regulate maintenance of neural progenitors. Neuron 58: 52-64.

SIDMAN, R.L., MIALE, I.L. and FEDER, N. (1959). Cell proliferation and migration in the primitive ependymal zone: an autoradiographic study of histogenesis in the nervous system. Exp Neuro/1: 322-333.

TAKAHASHI, T., NOWAKOWSKI, R.S. and CAVINESS, V.S., JR. (1993). Cell cycle parameters and patterns of nuclear movement in the neocortical proliferative zone of the fetal mouse. JNeurosci13: 820-833.

TAKENAKA, K., MORIGUCHI, T. and NISHIDA, E. (1998). Activation of the protein kinase p38 in the spindle assembly checkpoint and mitotic arrest. Science 280 599-602.

TAMAI, H., SHINOHARA, H., MIYATA, T., SAITO, K., NISHIZAWA, Y., NOMURA T. and OSUMI, N. (2007). Pax6 transcription factor is required for the interkinetic nuclear movement of neuroepithelial cells. Genes Cells 12: 983-996.

TOKUNAGA, A., KOHYAMA, J., YOSHIDA, T., NAKAO, K., SAWAMOTO, K. and OKANO, H. (2004). Mapping spatio-temporal activation of Notch signaling during neurogenesis and gliogenesis in the developing mouse brain. JNeurochem 90: $142-154$

TOMLINSON, A. (1988). Cellular interactions in the developing Drosophila eye. Development 104: 183-193.

TSAI, J.W., CHEN, Y., KRIEGSTEIN, A.R. and VALLEE, R.B. (2005). LIS1 RNA interference blocks neural stem cell division, morphogenesis, and motility at multiple stages. J Cel/ Biol170: 935-945

TURNER, D.L. and WEINTRAUB, H. (1994). Expression of achaete-scute homolog 3 in Xenopus embryos converts ectodermal cells to a neural fate. Genes Dev8 1434-1447.

UENO, M., KATAYAMA, K., YAMAUCHI, H., NAKAYAMA, H. and DOI, K. (2006). Cell cycle progression is required for nuclear migration of neural progenitor cells. Brain Res 1088: 57-67.

VASUDEVAN, S., TONG, Y. and STEITZ, J.A. (2008). Cell-cycle control of microRNA-mediated translation regulation. Cell Cycle 7: 1545-1549.

VERNON, A.E., DEVINE, C. and PHILPOTT, A. (2003). The cdk inhibitor p27Xic1 is required for differentiation of primary neurones in Xenopus. Development 130: $85-92$ 
WANG, W., CALDWELL, M.C., LIN, S., FURNEAUX, H. and GOROSPE, M. (2000). HuR regulates cyclin $A$ and cyclin $B 1$ mRNA stability during cell proliferation. EMBO J19: 2340-2350.

WATERSON, R.L., VENEZIANO, P. and BARTHA, A. (1956). Absence of a true germinal zone in neural tubes of young chick embryos as demonstrated by the colchicine technique. Anat Rec 124: 379.

WEBSTER, W. and LANGMAN, J. (1978). The effect of cytochalasin B on the neuroepithelial cells of the mouse embryo. Am J Anat 152: 209-221.

WEINMASTER, G. (2000). Notch signal transduction: a real rip and more. Curr Opin Genet Dev 10: 363-369.

WHITED, J.L., CASSELL, A., BROUILLETTE, M. and GARRITY, P.A. (2004). Dynactin is required to maintain nuclear position within postmitotic Drosophila photoreceptor neurons. Development 131: 4677-4686.

WIGHTMAN, B., HA, I. and RUVKUN, G. (1993). Posttranscriptional regulation of the heterochronic gene lin-14 by lin- 4 mediates temporal pattern formation in $\mathrm{C}$. elegans. Cel/75: 855-862.

WILCOCK, A.C., SWEDLOW, J.R. and STOREY, K.G. (2007). Mitotic spindle orientation distinguishes stem cell and terminal modes of neuron production in the early spinal cord. Development 134: 1943-1954.
WULCZYN, F.G., SMIRNOVA, L., RYBAK, A., BRANDT, C., KWIDZINSKI, E. NINNEMANN, O., STREHLE, M., SEILER, A., SCHUMACHER, S. and NITSCH, R. (2007). Post-transcriptional regulation of the let-7 microRNA during neural cell specification. FASEB J21: 415-426.

WYNSHAW-BORIS, A. and GAMBELLO, M.J. (2001). LIS1 and dynein motor function in neuronal migration and development. Genes Dev 15: 639-651.

XIE, Z., MOY, L.Y., SANADA, K., ZHOU, Y., BUCHMAN, J.J. and TSAI, L.H. (2007) Cep120 and TACCs control interkinetic nuclear migration and the neural progenitor pool. Neuron 56: 79-93.

YUGAWA, T., HANDA, K., NARISAWA-SAITO, M., OHNO, S., FUJITA, M. and KIYONO, T. (2007). Regulation of Notch1 gene expression by p53 in epithelial cells. Mol Cell Bio/27: 3732-3742.

ZINDY, F., CUNNINGHAM, J.J., SHERR, C.J., JOGAL, S., SMEYNE, R.J. and ROUSSEL, M.F. (1999). Postnatal neuronal proliferation in mice lacking Ink4d and Kip1 inhibitors of cyclin-dependent kinases. Proc Natl Acad Sci USA 96: 13462-13467.

ZUBER, M.E., PERRON, M., PHILPOTT, A., BANG, A. and HARRIS, W.A. (1999) Giant eyes in Xenopus laevis by overexpression of XOptx2. Cel/98: 341-352.

\section{Further Related Reading, published previously in the Int. J. Dev. Biol.}

See our recent Special Issue Developmental Genetics of Drosophila edited by Alain Ghysen at:

http://www.ijdb.ehu.es/web/contents.php?vol=42\&issue=3

«Notch-Off»: a perspective on the termination of Notch signalling

Rita Fior and Domingos Henrique

Int. J. Dev. Biol. (2009) 53: doi: 10.1387/ijdb.072309rf

Establishment of a proneural field in the inner ear

Gina Abelló and Berta Alsina

Int. J. Dev. Biol. (2007) 51: 483-493

Notch in vertebrates - molecular aspects of the signal

Ken-Ichi Katsube and Kei Sakamoto

Int. J. Dev. Biol. (2005) 49: 369-374

Notch activity is required to maintain floorplate identity and to control neurogenesis in the chick hindbrain and spinal cord

Isabelle le Roux, Julian Lewis and David Ish-Horowicz

Int. J. Dev. Biol. (2003) 47: 263-272

Evolution of cis-regulation of the proneural genes

Jean-Michel Gibert and Pat Simpson

Int. J. Dev. Biol. (2003) 47: 643-651

Cysteine-rich region of X-Serrate-1 is required for activation of Notch signaling

in Xenopus primary neurogenesis

Tomomi Kiyota and Tsutomu Kinoshita

Int. J. Dev. Biol. (2002) 46: 1057-1060

Diverse requirements for Notch signalling in mammals

Duncan B Sparrow, Melanie Clements, Sarah L Withington, Annabelle N Scott, Jiri Novotny, David Sillence, Kenro Kusumi, Rosa S P Beddington and Sally L Dunwoodie

Int. J. Dev. Biol. (2002) 46: 365-374

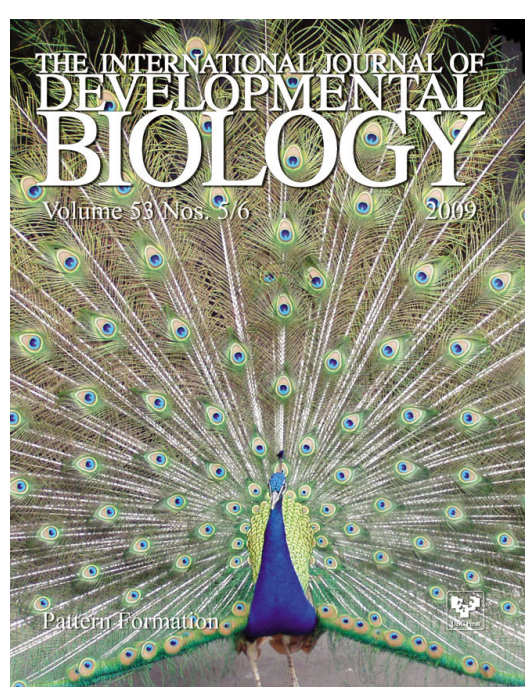

5 yr ISI Impact Factor $(2008)=3.271$

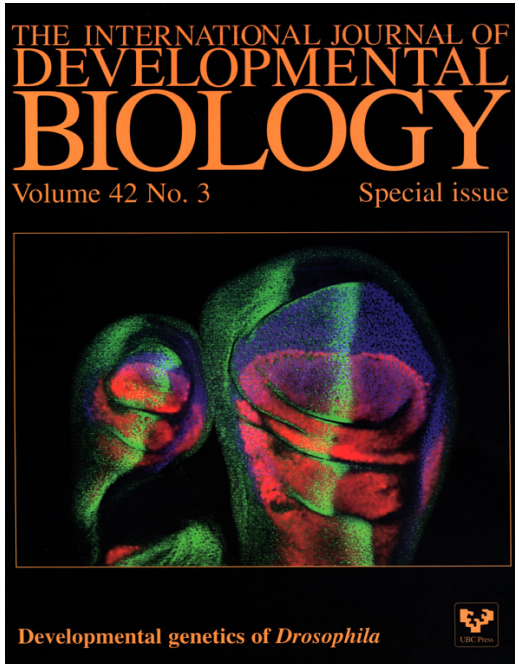

